Article

\title{
Ecological-Health Risks of Potentially Toxic Metals in Mangrove Sediments near Estuaries after Years of Piggery Farming Bans in Peninsular Malaysia
}

\author{
Chee Kong Yap ${ }^{1, *(1)}$ and Khalid Awadh Al-Mutairi ${ }^{2}$ \\ 1 Department of Biology, Faculty of Science, Universiti Putra Malaysia (UPM), \\ Serdang 43400, Selangor, Malaysia \\ 2 Department of Biology, Faculty of Science, University of Tabuk, \\ Tabuk P.O. Box 741, Saudi Arabia; kmutairi@ut.edu.sa \\ * Correspondence: yapckong@hotmail.com or yapchee@upm.edu.my
}

check for updates

Citation: Yap, C.K.; Al-Mutairi, K.A. Ecological-Health Risks of Potentially Toxic Metals in Mangrove Sediments near Estuaries after Years of Piggery Farming Bans in Peninsular Malaysia. Sustainability 2022, 14, 1525. https:// doi.org/10.3390/su14031525

Academic Editors: Balram Ambade, Lekhendra Tripathee and Ram Lal Verma

Received: 13 January 2022 Accepted: 26 January 2022 Published: 28 January 2022

Publisher's Note: MDPI stays neutral with regard to jurisdictional claims in published maps and institutional affiliations.

Copyright: (C) 2022 by the authors. Licensee MDPI, Basel, Switzerland. This article is an open access article distributed under the terms and conditions of the Creative Commons Attribution (CC BY) license (https:// creativecommons.org/licenses/by/ $4.0 /)$.
Simple Summary: The Sepang Besar River (SBR) was reported to be highly contaminated with $\mathrm{Cu}$ and $\mathrm{Zn}$ due to piggery farming wastes before 1998. Following the piggery farming ban (PFB) in 1998 in Bukit Pelanduk, the present study aimed to assess the ecological-health risks of potentially toxic metals (PTMs) in the mangrove surface sediments from the SBR estuary. The PTMs of current sediment samples collected in 2007 and 2010 were compared with those reported before and after PFB. Overall, the results of $\mathrm{Cu}$ and $\mathrm{Zn}$ were drastically lower than those reported before or during the PFB. The non-carcinogenic risk based on the pathways of $\mathrm{Cu}, \mathrm{Pb}$, and $\mathrm{Zn}$ indicated that the three rivers had caused no ecological-health risks of the three metals. In particular, the SBR estuary had drastically lower levels of $\mathrm{Zn}$ after 9 and 12 years of PFB. The potential ecological risk index showed that the estuary of SBR has been improved from a "considerable ecological risk" to a "minimal ecological risk" after 9 and 12 years of PFB. This is the first paper on the ecological-health risks of $\mathrm{Cu}, \mathrm{Pb}$, and $\mathrm{Zn}$ in the estuary of SBR.

Abstract: The Sepang Besar River (SBR) was reported to be highly contaminated with Cu and Zn due to piggery farming wastes before 1998. Following the piggery farming ban (PFB) in 1998 in Bukit Pelanduk, the present study aimed to assess the ecological-health risks of potentially toxic metals (PTMs) ( $\mathrm{Cu}, \mathrm{Pb}$, and $\mathrm{Zn})$ in the mangrove surface sediments from SBR. Two adjacent rivers, namely the Sepang Kecil River and Lukut River, were also included for comparison purposes. The PTMs of present sediment samples collected in 2007 and 2010 were compared with those reported before and after PFB. The PTMs levels were lower than those of established sediment quality guidelines. Results of bioavailable fractions, individual contamination factor, risk assessment code, potentially ecological risk index (PERI), and non-carcinogenic risk (with $\mathrm{HI}<1.0$ based on the pathways of $\mathrm{Cu}, \mathrm{Pb}$, and $\mathrm{Zn}$ and the order: ingestion $>$ dermal contact $>$ inhalation), the present findings indicated that the three rivers had caused no ecological-health risks of $\mathrm{Cu}, \mathrm{Pb}$, and $\mathrm{Zn}$. In particular, SBR estuary had drastic lower levels of $\mathrm{Zn}$ (7.48-9.40 times lower between 1998 and 2010) and $\mathrm{Cu}$ (8.30-36.9 times lower between 1998 and 2010), after 12 years of PFB. Based on the exponential decay model, the PERI values showed that the estuary of SBR has been improved from a "considerable ecological risk" to a "minimal ecological risk" after 12 years of PFB. This is the first paper on the ecological-health risks of $\mathrm{Cu}, \mathrm{Pb}$, and $\mathrm{Zn}$ in the estuary of SBR. Future monitoring is still necessary for effective risk management of the mangrove ecosystem at SBR.

Keywords: ecological risk; potentially toxic metals; Peninsular Malaysia; surface sediments; mangrove

\section{Introduction}

The 1998 outbreak of novel Nipah disease (Japanese encephalitis) at Bukit Pelanduk, located upstream of Sepang Besar River (SBR), in Negeri Sembilan, Peninsular Malaysia, 
had stumbled socially and economically [1]. After that, the piggery farming ban (PFB) in Bukit Pelanduk was in force in 1998 [2], in which Bukit Pelanduk once had the most significant pig farming community in Southeast Asia [3,4]. Ismail and Ramli [5] reported elevated levels of two potentially toxic metals (PTMs) ( $\mathrm{Cu}$ and $\mathrm{Zn}$ ) in the sediments collected from the upstream of SBR before 1998 [6], which were dominated by anthropogenic inputs of piggery effluents. From the ecotoxicological standpoint, the status of PTMs in the sediments after the closure of the piggery farming operation is highly sought after.

Generally, sediment contamination with PTMs could be either from natural geogenic sources or anthropogenic inputs, such as untreated solid waste, both industrially and domestically [7]. In the case of SBR, even though the source of anthropogenic piggery effluent had been stopped due to PFB, the metal-contaminated sediments could become a secondary source of PTMs to the sediment-dwelling organisms [8], and thus could pose an ecotoxicological concern. Once PTMs enter the river, depending on the physicochemical characteristics of the river, they may be adsorbed to suspended particulate matter and later deposited to the sediments under the gravitational force [9]. Therefore, the contaminated sediments can act as non-point sources of PTMs in the water column $[10,11]$ when the chemistries, such as $\mathrm{pH}$, redox conditions, and salinity of the aquatic system, change $[12,13]$. The metals present in the sediments can be re-released into the water, thus causing secondary pollution [14]. This can cause significant damage to the ecological status of the aquatic ecosystem [15]. Consequently, where sediments act as a "sink" or "secondary source" for PTMs, the sediments can be used as an effective environmental medium to monitor and evaluate the magnitude and sources of PTMs pollution in the estuaries [16,17], and mangrove ecosystem [18-21]. In particular, the comparison of PTMs concentrations in SBR sediments before and after years of the PFB with sediment quality guidelines is important for determining the likelihood that such sediments would be toxic or not to aquatic and sediment-dwelling organisms [22,23].

The main reason we focused on the estuary of the SBR is that estuaries are dynamic ecosystems that have some of the highest biotic diversity and levels of productive resources in the world [24]. The rate at which river water flows into an estuary is mainly responsible for establishing specific estuarine characteristics over time [25]. The estuaries and their surrounding mangrove ecosystems are bodies of water usually found where rivers meet the sea. They can serve as a habitat for residents and migratory animals, engaging an essential role in carbon sequestration and protection against coastal erosion [19,21]. Among chemical pollutants, PTMs can cause a significant adverse effect on the ecological quality of mangrove ecosystems [20]. Consequently, conservation strategies in mangrove ecosystems have always been on the rise [18]. This has been the main reason why ecological studies on the estuarine ecosystem have been widely reported in the literature (e.g., Noe et al. [26]). In Malaysia, Alkarkhi et al. [27] studied the PTMs in the sediments from estuaries of two polluted rivers in Malaysia (Juru River and Jejawi River). They recommended the need for a monitoring network. Therefore, the present study is critical from a monitoring to a conservation point of view.

Two questions have been raised about the historical fact of the previously polluted SBR. Firstly, Is the PFB in 1998 having any reduction or effect in controlling the PTMs pollution in the surface sediments at the estuary of the SBR after 9 and 12 years? Secondly, Is the polluted sediments at SBR still posing ecological-health risks of PTMs after 9 and 12 years of PFB?

However, little information is available on the assessments of ecological-health risks of PTMs in the estuaries of the SBR mangrove area and its two adjacent rivers, namely Sepang Kecil River (SKR) and Lukut River (LR). Therefore, this study aimed (1) to quantify the concentrations of $\mathrm{Cu}, \mathrm{Pb}$, and $\mathrm{Zn}$ in the surface sediments of SBR estuary after 9 and 12 years of PFB, and (2) to assess the ecological-health risks of the three PTMs in the mangrove sediments of the three river estuaries. 


\section{Materials and Methods}

\subsection{Sampling Site Descriptions}

Convenient samplings of surface sediments $(0-10 \mathrm{~cm})$ were done at the estuaries of six sampling sites in the SBR (S1-S6), three sampling sites in SKR (S7-S9), and five sampling sites in LR (L1-L5), on 1 December 2007 (Figure 1). The second-period sampling in the SBR estuary was conducted on 5 May 2010. In both 2007 and 2010, the sampling sites chosen were at the estuary section of the SBR so that they are comparable to those previously reported before PFB in 1998.

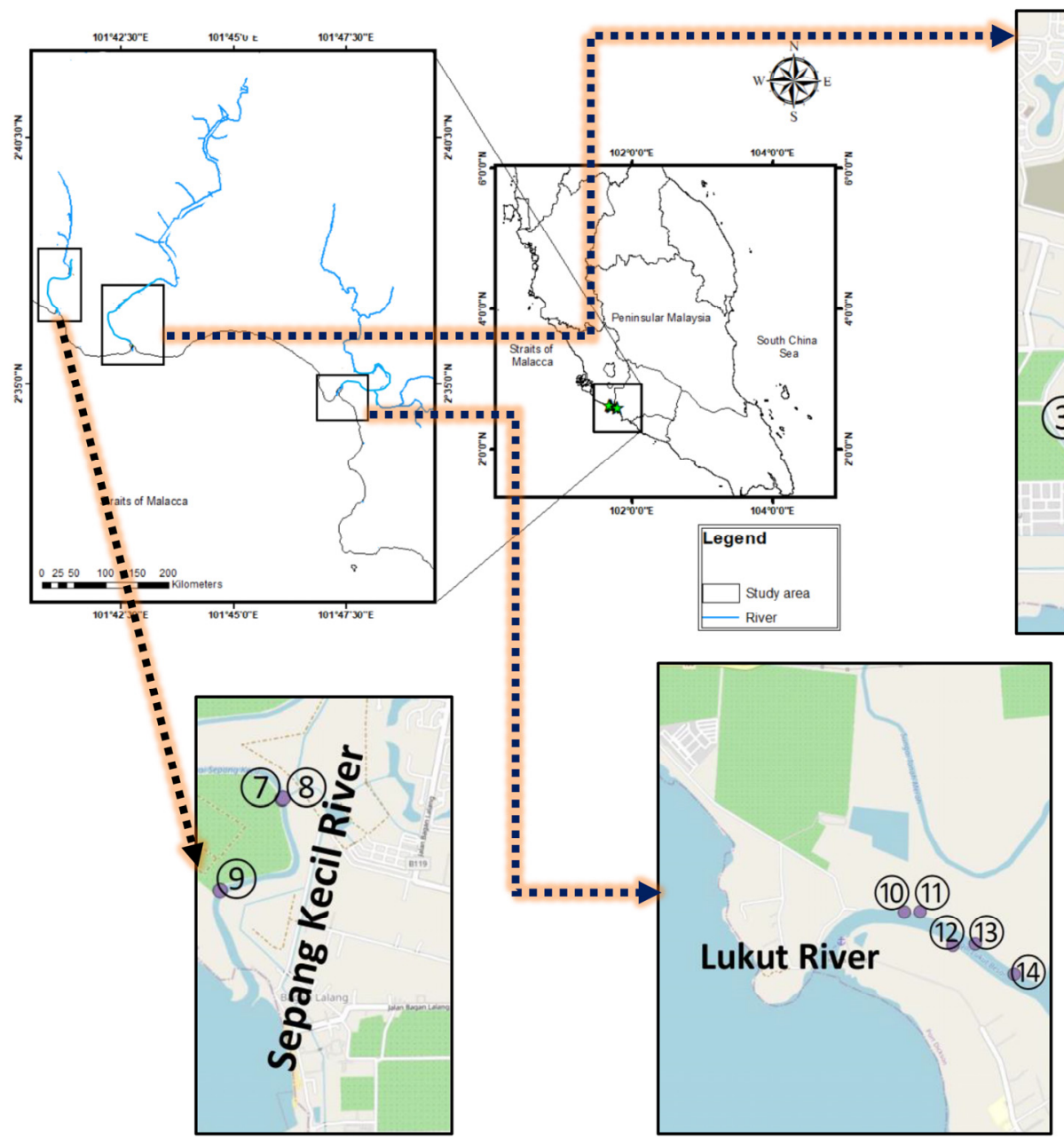

Figure 1. Sampling sites in the Sepang Besar River (SBR) (1-6), Sepang Kecil River (7-9), and Lukut River (10-14) in 2007, and arrows in black with sampling numbers with black grounds are those collected in 2010 in SBR. (The maps were generated by using QGIS Desktop version 2.18.13).

Sampling information is provided in Table S1. At each sampling site, about $2 \mathrm{~kg}$ of surface sediments $(0-10 \mathrm{~cm})$ were collected from the sampling site by using a stainless-steel shovel. The samples were placed in zipped-lock polyethylene bags and transferred to the laboratory.

Upon reaching the laboratory, the sediment samples were oven-dried at $80{ }^{\circ} \mathrm{C}$ for $72 \mathrm{~h}$ and passed through a $2 \mathrm{~mm}$ nylon sieve to remove external particle materials. The dried sediments were passed through $63 \mu \mathrm{m}$ sieves to dissolve in the acid digestion of the sedimentary particles completely for heavy metal analysis. This was because the highest metal concentrations, such as $\mathrm{Pb}$, were in the smallest fraction analyzed $(<63 \mu \mathrm{m})$ for the assessment of incidental ingestion [28,29]. 


\subsection{Metal Analysis}

\subsubsection{Acid Digestions}

The direct aqua-regia, which is a wet digestion method, was used to digest the sediment samples. A total of $0.50 \mathrm{~g}$ of dried sediment samples was placed in a digestion tube (3 replicates). The aqua-regia is a mixture of nitric acid $\left(\mathrm{HNO}_{3} ;\right.$ AnalaR grade, $\mathrm{BDH} 69 \%$ ) and perchloric acid $\left(\mathrm{HClO}_{3}\right.$; AnalaR grade, $\left.\mathrm{BDH} 60-70 \%\right)$, in a ratio of $4: 1$

The sediments were fractionated into four fractions based on Badri and Aston [30]. These four fractions employed in this study were (i) 'easily, freely, leachable, or exchangeable' (EFLE); (ii) 'acid-reducible' (AR); (iii) 'oxidizable-organic' (OO); and (iv) 'resistant' (RES).

Samples were then placed in a digestion block at $40{ }^{\circ} \mathrm{C}$ for $1 \mathrm{~h}$, and the samples were then fully digested at $140{ }^{\circ} \mathrm{C}$ for $3 \mathrm{~h}$ [6,31]. They were then diluted to $40 \mathrm{~mL}$ with double de-ionized water. Later, the diluted samples were filtered through Whatman No. 1 (filter speed: medium) filter paper into acid-washed pillboxes and stored at $4{ }^{\circ} \mathrm{C}$ until metal determination. The solution was analyzed using an air-acetylene flame atomic absorption spectrophotometer (FAAS, Perkin-Elmer Model AAnalyst 800; Perkin-Elmer LLC, CT, USA).

\subsubsection{Quality Control for Heavy Metal Analysis}

All glassware and equipment used were acid-washed to avoid external contamination. Procedural blanks and quality control samples made from the standard solution for each metal were analyzed along with the digested samples. These standard solutions were analyzed after every 5-10 samples to check for the accuracy of the analyzed samples [6,31]. The accuracy of the methods for the analysis of $\mathrm{Cu}, \mathrm{Pb}$, and $\mathrm{Zn}$ was verified with the Certified Reference Materials (CRM) of NSC DC73319 Soil China, MESS-3 NRC, TH-1 Sediment Canada, SRM 1547, and IAEA Soil-5. Comparisons of the percentage recoveries for the six metals between the certified values of the CRM and the measured concentrations are presented in Table S2. The recoveries were 85.0-93.1\% for $\mathrm{Cu}, 99.8-116$ for $\mathrm{Pb}$, and $82.8-115 \%$ for $\mathrm{Zn}$ (Table S2). The detection limits of the FAAS for $\mathrm{Cu}, \mathrm{Pb}$, and $\mathrm{Zn}$ were $0.010,0.009$, and $0.007 \mathrm{mg} / \mathrm{L}$, respectively.

\subsection{Data Treatment}

\subsubsection{Sediment Quality Guidelines (SQGs)}

The sediment quality guidelines and reference values used in the present study are shown in Table S3. Three sediment quality guidelines were used. They are interim sediment quality value (ISQV) (high and low) by Chapman et al. [8], threshold effect level (TEL) and probable effect level (PEL) by Macdonald et al. [23], and effect range low (ERL) and effects range median (ERM) by Long et al. [22].

\subsubsection{Determination of Bioavailable and Non-Bioavailable Fractions}

Based on the geochemical fractions of the sediments, the bioavailable fraction and non-bioavailable fractions were generated by (EFLE + AR)/(EFLE + AR + OO + RES), and $(\mathrm{OO}+\mathrm{RES}) /(\mathrm{EFLE}+\mathrm{AR}+\mathrm{OO}+\mathrm{RES})$, respectively [32].

\subsubsection{Individual Contamination Factors (ICF)}

The individual contamination factors (ICF) was calculated based on (EFLE + AR + OO) by the RES of the sediment samples $[33,34]$. The ICF classification was interpreted as ICF $<0$ (low); $1<$ ICF $<3$ (moderate); $3<$ ICF < 6 (considerable); ICF > 6 (high), contamination [35].

\subsubsection{Risk Assessment Code (RAC)}

The risk assessment code (RAC) was calculated by EFLE/(EFLE + AR + OO + RES), according to Perin et al. [36] which was used to evaluate the bioavailability and mobility of metals in sediments. The RAC is classified into five classes: Class I (no risk, RAC $<1$ ); 
Class II (low risk, $1<$ RAC < 10); Class III (medium risk, $11<\mathrm{RAC}<30$ ); Class IV (high risk, $31<\mathrm{RAC}<50$ ); and Class V (very high risk, RAC $>50$ ).

\subsubsection{Ecological Risk Index (ER)}

Firstly, the calculation of the contamination factor (CF) was based on the pollution of a single metal factor in Equation (1).

$$
\mathrm{CF}=\frac{\mathrm{C}_{\mathrm{s}}}{\mathrm{C}_{\mathrm{B}}}
$$

where $C_{S}$ is the concentration of PTM in the surface sediments; $C_{B}$ is the background values in the present study and was based on two values. Firstly, the UCC by Wedepohl [37] for $\mathrm{Cu}$ : 14.30, $\mathrm{Zn:}$ 52.0, and $\mathrm{Pb}$ : 17.0 were used. Secondly, the concentrations (mg/kg dry weight (dw)) were 19.48, 3.55, and 13.16 for $\mathrm{Pb}$ [38], $\mathrm{Cu}$ [31], and $\mathrm{Zn} \mathrm{[39],} \mathrm{respectively,} \mathrm{based}$ on the intertidal area of Peninsular Malaysia.

Later, the calculation of ecological risk (ER), which is the potential ecological risk of a single element, was calculated based on Equation (2).

$$
\mathrm{ER}=\mathrm{T}_{\mathrm{R}} \times \mathrm{Cf}
$$

where $T_{R}$ is the toxic response factor of a single element. The $T_{R}$ values used in the present study are $\mathrm{Cu}=5.00, \mathrm{~Pb}=5.00$, and $\mathrm{Zn}=1.00$ [40]. $\mathrm{CF}$ is the contamination factor calculated as described in Equation (1). According to Hakanson [40], the ER can be classified into: 'low potential ecological risk' (ER < 40); 'moderate potential ecological risk' $(40 \leq \mathrm{ER}<80)$; 'considerable potential ecological risk' (80 $\leq \mathrm{ER}<160)$; 'high potential ecological risk' (160 $\leq \mathrm{ER}<320)$; and 'very high ecological risk' (ER $\geq 320)$.

\subsubsection{Potential Ecological Risk Index (PERI)}

Potential ecological risk index (PERI) was the summation of all the ER values from each PTM (Hakanson, 1980) [40]. It was calculated based on Equation (3).

$$
\mathrm{ERI}=\sum \mathrm{ER}
$$

According to Hakanson [40], the PERI values can be classified into: 'low ecological risk' (PERI < 150); 'moderate ecological risk' (150 < PERI < 300); 'considerable ecological risk' (300 $\leq$ PERI < 600); and 'very high ecological risk' (PERI $\geq 600)$. This index is used to assess the potential ecological risk level of PTEs in sediments to the environment [41,42]. Although this method is based on sedimentology and aquatic ecosystem principles, it has been used in sediment pollution evaluation [43,44].

\section{Human Health Risk Assessment}

Human health risk assessment (HHRA) of sediments is generally utilized to assess humans' non-carcinogenic risk (NCR) using three exposure pathways: ingestion, inhalation, and dermal contact. The methodology used for the HHRA depended on the guidelines and Exposure Factors Handbook of the US Environmental Protection Agency [45-48]. The average daily doses (ADDs) (mg/kg day) of PTMs through ingestion ( ADD $_{\text {ing }}$ ), inhalation $\left(\mathrm{ADD}_{\mathrm{inh}}\right)$, and dermal contact $\left(\mathrm{ADD}_{\mathrm{der}}\right)$ for both children and adults were calculated by using Equation (4) as follows:

$$
\begin{gathered}
\mathrm{ADD}_{\text {ing }}=\mathrm{C}_{\text {sediment }}\left(\frac{\mathrm{IngR} \times \mathrm{EF} \times \mathrm{ED}}{\mathrm{BW} \times \mathrm{AT}}\right) \times 10 \\
\mathrm{ADD}_{\text {inh }}=\mathrm{C}_{\text {sediment }}\left(\frac{\mathrm{InghR} \times \mathrm{EF} \times \mathrm{ED}}{\mathrm{PEF} \times \mathrm{BW} \times \mathrm{AT}}\right) \\
\mathrm{ADD}_{\text {der }}=\mathrm{C}_{\text {sediment }}\left(\frac{\mathrm{SA} \times \mathrm{AF} \times \mathrm{ABS} \times \mathrm{EF} \times \mathrm{ED}}{\mathrm{BW} \times \mathrm{AT}}\right) \times 10^{-6}
\end{gathered}
$$


where $\mathrm{ADD}_{\text {ing, }} \mathrm{ADD}_{\text {inh, }}$ and $\mathrm{ADD}_{\mathrm{der}}$ are the daily amounts of exposure to metals $(\mathrm{mg} / \mathrm{kg}$ day) through ingestion, inhalation, and dermal contact, respectively. In this study, the NCR of PTMs was assessed by using the hazard quotient (HQ) and hazard index (HI) $[49,50]$. The definition, exposure factors, and reference values used to estimate the intake values and health risks of PTMs in sediments collected from Peninsular Malaysia are presented in Table S4.

The HQ is the proportion of the ADD of a metal to its reference dose (RfD) for the similar exposure pathway(s) [47]. The RfD ( $\mathrm{mg} / \mathrm{kg}$ day) is the maximum daily dose of metal from a particular exposure pathway, for both children and adults, that is accepted not to prompt a considerable risk of harmful effects to sensitive individuals during a lifetime. The $\mathrm{RfD}$ ( $\mathrm{mg} / \mathrm{kg}$ day) values of $\mathrm{Cu}, \mathrm{Pb}$, and $\mathrm{Zn}$ used in the present study for ingestion, inhalation, and dermal contact, are presented in Table S4. If the ADD is less than the RfD value $(H Q \leq 1)$, it is viewed as that there will be no adverse health effects, while if the ADD exceeds the RfD value (HQ > 1), there will likely be harmful health effects $[45,47]$.

The NCR is assessed by HI, which is the summation of the HQs in the three exposure pathways [51-53]. HI of $<1.0$ indicates no significant risk of non-carcinogenic effects. A $\mathrm{HI}$ of $>1.0$ suggests a possible occurrence of non-carcinogenic impacts [54]. The HI was calculated according to Equation (7).

$$
\mathrm{HI}=\sum \mathrm{HQ}_{\mathrm{i}}=\sum\left(\frac{\mathrm{ADD}_{\mathrm{i}}}{\mathrm{RfD}_{\mathrm{i}}}\right)
$$

\section{Statistical Analysis}

All graphical bar charts were plotted using the KaleidaGraph (Version 3.08, Sygnergy Software, Eden Prairie, MN, USA). In the graphs, curve fit selected an exponential regression for modeling the relationship between the metal levels or PERI values and periods of sediments collected after years of PFB. This exponential decay model is logically acceptable and appropriate because it gave the best plot with a decay constant $(\lambda)$ (with an $R$-value) for the relationships that fit the purpose of this study well, namely the decrement of metal levels to background levels of metals in the sediments.

All the concentrations data of $\mathrm{Cu}, \mathrm{Pb}$, and $\mathrm{Zn}$ in the present study were within the normality ranges based on skewness $(-2$ to +2$)$ and kurtosis $(-7$ to +7$)[55,56]$ (Tables S5, S7 and S9).

\section{Results}

\section{1. $\mathrm{Zn}$}

Table S5 shows the concentrations of total Zn, percentages of four geochemical fractions, percentages of bioavailable fraction (Bio), and a non-bioavailable fraction (NonBio), ICF, and RAC for Zn. Based on 2007 samples, the Zn concentrations (mg/kg dw) ranged from 18.1-88.25 (mean: 68.06) in SBR, from 52.27-98.97 (mean: 69.55) in SKR, and from 45.52-79.34 (mean: 67.1) in LR. The SBR estuary of 2010 samples ranged from 14.7-26.6 (mean: 19.99). Collected from LR, Ismail, and Safahieh [57] reported that Zn ranged from $48.2-209 \mathrm{mg} / \mathrm{kg} \mathrm{dw}$, with $40-60 \%$ in the metal contributed by the nonresistant fractions related to anthropogenic sources.

When comparing to the SGQ values (Table S3), all Zn levels were below those by Chapman et al. [8], Macdonald et al. [23], and Long et al. [22]. When compared to the reference background values (Table S3), the mean Zn levels of the three rivers of 2007 samples were higher than the background Zn levels proposed by Wedepohl [37] and Yap et al. [39]. The mean Zn level of 2010 samples from SBR was slightly higher than the background Zn level by Yap et al. [39].

However, it should be noted that the sampling sites as reported by Saed et al. [58] in SBR covered the first two sites near the river mouth, which was relevant and comparable to the present study. All the sampling sites at SBR from the present study covered the river mouth section. Specifically, Saed et al. [58] reported Zn levels as $110-250 \mathrm{mg} / \mathrm{kg}$ 
dw on the two sites near the river mouth at SBR. After 5 years of PFB, the Zn levels had decreased (35.5 to $179 \mathrm{mg} / \mathrm{kg} \mathrm{dw}$ ) based on 2003 samples [6], with 3.1-1.39 times lower. The $\mathrm{Zn}$ decrement percentages were further increased (2.83-6.07 times lower) based on 2007 samples after 9 years of PFB. The Zn levels continually dropped after 12 years of PFB (14.7-26.6 mg/kg dw) based on 2010 samples.

In particular, at the estuary section of SBR, there has been a decline of $\mathrm{Zn}$ levels from 110-250, 35.5-179, 18.8-88.25, and 14.7-26.6 for samples from 1998, 2003, 2007, and 2010, respectively (Figure 2). Figure 2 used an exponential decay model to estimate the best plot with a decay constant $(\lambda)$ of $0.13(R=0.87 ; p<0.05)$ to summarize the negative relationship between Zn levels and years after years of PFB. Furthermore, this model is logically selected and acceptable because there will be background levels of metals in the sediments that would not reach zero background levels in any natural sediments of the world [37]. This exponential regression can model a situation of a faster decrement of $\mathrm{Zn}$ levels in the estuary of SBR sediments in the first few years after PFB and a lower decrement after 12 years of PFB in 2010.

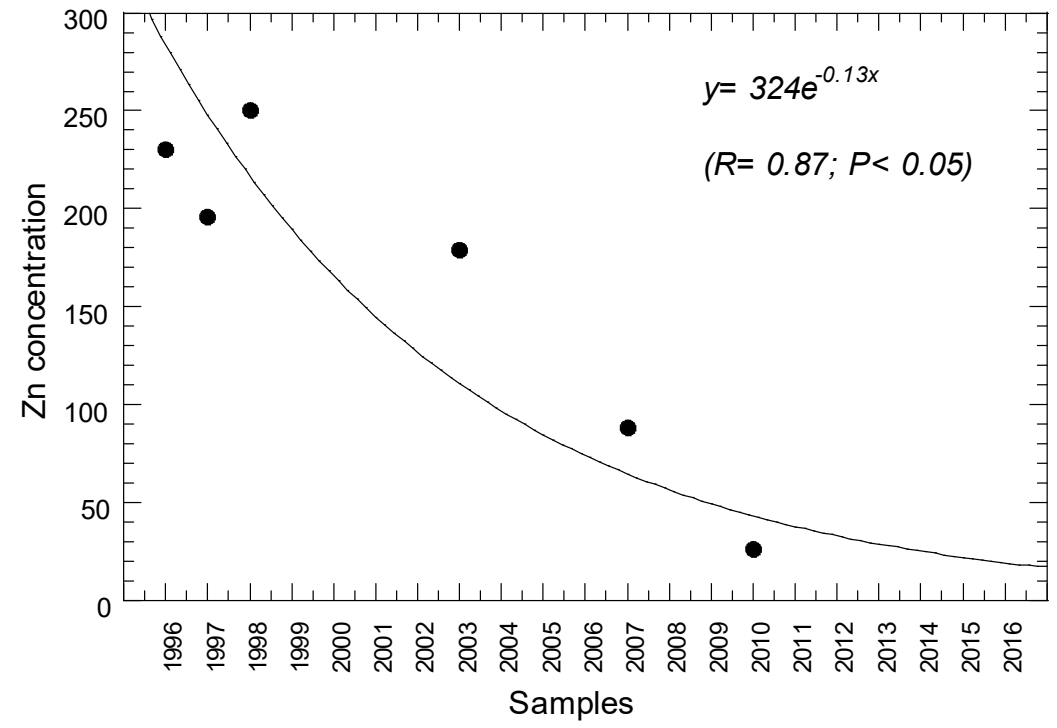

Figure 2. Decreasing Zn concentrations (mg/kg dry weight) in the surface sediments from Sepang Besar River estuary in the samples from 1996 (Ismail and Ramli, 1997), 1997 (Hossain, 2000), 1998 (Saed et al., 2002), 2003 (5 years after the piggery farm ban) (Yap et al., 2007), 2007 (9 years after the piggery farm ban) (present study), and 2010 (12 years after the piggery farm ban) (present study). The equation on the maximum values is based on an exponential equation.

Most interestingly, based on samples collected in 1998 near the piggery farm upstream of SBR (Pelanduk River and Rambai River), Saed et al. [58] reported the Zn levels near the piggery farm ranged from 430 to $602 \mathrm{mg} / \mathrm{kg}$ dw. Previously, collected in 1996, Ismail and Ramli [5] reported high levels of Zn (250-550 mg/ $\mathrm{kg} \mathrm{dw})$ in the mangrove sediment upstream of SBR that received pig farm effluents. Later, Hossain (2000) also reported an elevated $\mathrm{Zn}$ range (461-1192 $\mathrm{mg} / \mathrm{kg} \mathrm{dw}$ ) in the sediments collected in 1997 from the upstream of SBR. These Zn maximum levels were practically higher than all the SQGs and reference values (Table S3). After 5 years of PFB, the sediments collected in 2003 at Pelanduk River recorded a lower Zn range (375-416 mg/kg dw) [6]. This means that there had been 1.46 and 1.45 times lower levels of $\mathrm{Zn}$ based on the ratios of minimum and maximum Zn levels from the 1998 and 2003 samples, respectively.

The distributions of four geochemical fractions of $\mathrm{Zn}$ in all the sampling sites from the present study are shown in Figure 3. The Bio fraction for Zn ranged from 25-36.5\% for LR, 8.59-34.24\% for SBR, and 14.40-37.7\% for SKR. These results indicated that the NonBio fraction dominated the total $\mathrm{Zn}$ concentrations by more than $50 \%$ in the three rivers. For $\mathrm{Zn}$ ICF, the values ranged from 1.39-2.46 (mean: 1.86) for LR, 0.67-1.55 (mean: 1.16) for SBR, 
and 1.10-1.87 (mean: 1.44) for SKR. For Zn RAC, the values ranged from $2.10-8.91 \%$ (mean: 3.83\%) for LR, 0.56-9.87\% (mean: $2.91 \%$ ) for SBR, and 0.73-6.44\% (mean: 3.71\%) for SKR. The values indicated that the three rivers are classified from 'no risk' to 'low risk' for Zn.

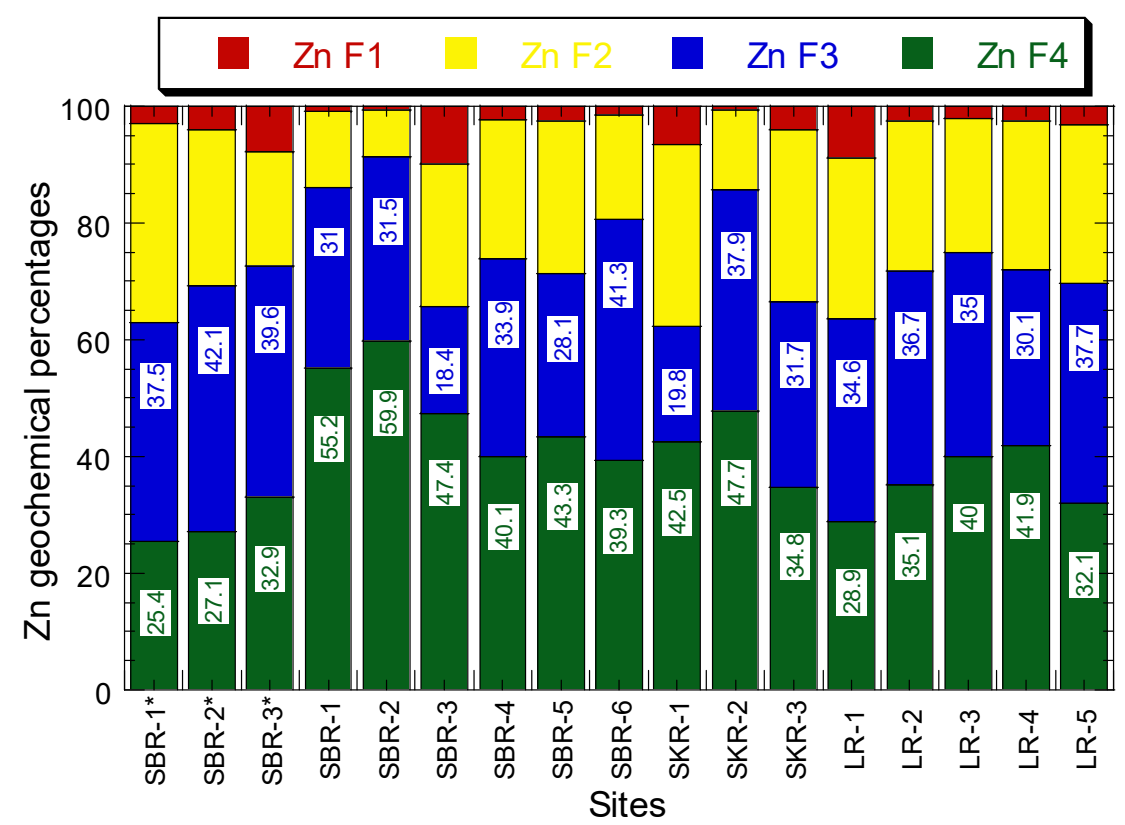

Figure 3. Distributions (\%) of four geochemical fractions (F1 = EFLE; F2 = acid-reducible; F3 = Oxidisable-organic; F4 = resistant) of $\mathrm{Zn}$ in all the sampling sites from Sepang Besar River (SBR), Sepang Kecil River (SKR) and Lukut River (LR) in the samples from the 2007 and 2010 (indicated by *).

The ranges of $\mathrm{Zn}$ ER values for all the sampling sites from the present study ranged from $0.28-1.90$ and 1.12-7.52 for ER-1 and ER-2, respectively (Figure 4). According to Hakanson's [40] classification, they were in the category of 'minimal potential ecological risk $(\mathrm{ER}<40)^{\prime}$.
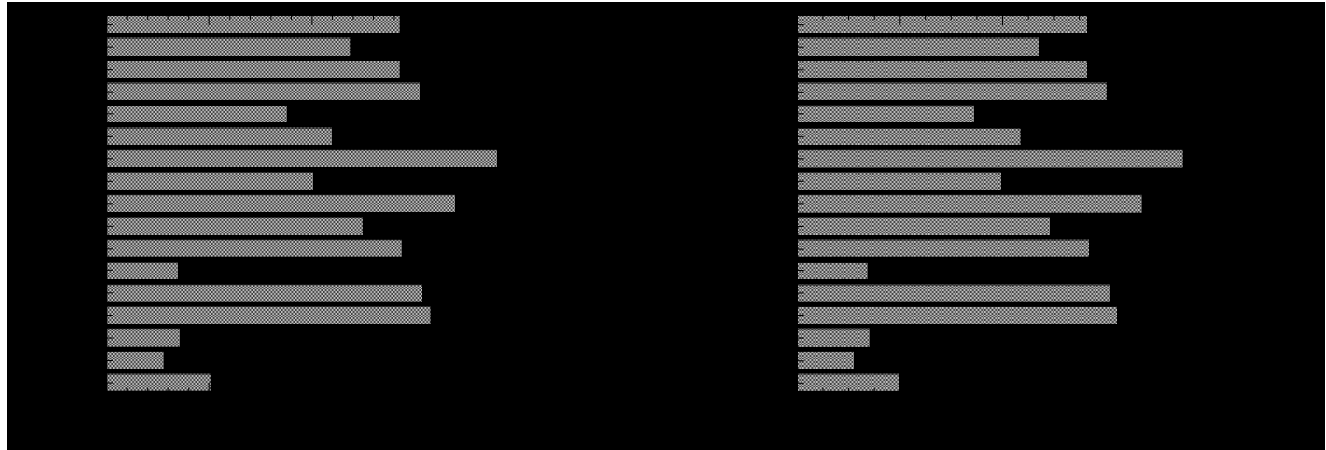

Figure 4. Ecological risk (ER) values of $\mathrm{Zn}$ in all the sampling sites from Sepang Besar River (SBR), Sepang Kecil River (SKR), and Lukut River (LR) in the samples from the 2007 and 2010 (indicated by *). The background used was based on background values by Wedepohl [37] (indicated by ER-1) and Malaysian studies (indicated by ER-2).

The HHRA results due to $\mathrm{Zn}$ exposure in the surface sediments from the three rivers are shown in Table S6. For children $\mathrm{Zn}$, based on the mean values from the rivers from

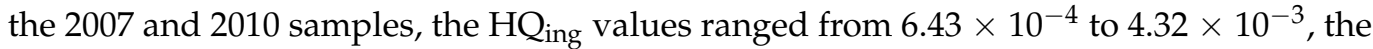
$\mathrm{HQ}_{\text {der }}$ values ranged from $5.14 \times 10^{-6}$ to $3.46 \times 10^{-5}$, while $\mathrm{HQ}_{\text {inh }}$ values ranged from $1.76 \times 10^{-8}$ to $1.18 \times 10^{-7}$. The children's HI ranged from $6.48 \times 10^{-4}$ to $4.36 \times 10^{-3}$. For adult $\mathrm{Zn}$, based on the mean values from the rivers of 2007 and 2010 samples, the HQing 
values ranged from $8.62 \times 10^{-5}$ to $5.80 \times 10^{-4}$, the $\mathrm{HQ}_{\mathrm{der}}$ values ranged from $1.31 \times 10^{-5}$ to $8.83 \times 10^{-5}$, while $\mathrm{HQ}_{\text {inh }}$ values ranged from $7.92 \times 10^{-9}$ to $5.33 \times 10^{-8}$. The adult $\mathrm{HI}$ ranged from $9.94 \times 10^{-5}$ to $6.69 \times 10^{-4}$.

Based on the maximum $\mathrm{Zn}$ HI values in both children and adults, all three $\mathrm{Zn}$ pathways followed SBR2 > SBR1 > SBR4 > LR3 > SKR2007 > SKR2 > SBR2007 > LR2007 > SBR2010. With all the HI values found below 1 in both children and adults, the estuary sediments from the three rivers would pose a non-unhealthy NCR of Zn. It was shown that the three different exposure pathways of $\mathrm{Zn}$ for children and adults diminished in the following order: ingestion $>$ dermal contact $>$ inhalation. This agreed with the reports by Yap et al. [59] based on the soils collected from six land uses in Peninsular Malaysia.

\section{2. $\mathrm{Cu}$}

Table S7 shows the concentrations of total $\mathrm{Cu}$, percentages of four geochemical fractions, percentages of bioavailable fraction (Bio) and non-bioavailable fraction (NonBio), $\mathrm{ICF}$, and RAC for $\mathrm{Cu}$. The present study is based on sediments collected from Sepang Besar River in December 2007; for Cu, SKR ranged from 7.96-13.48 (mean: 10.08), SBR ranged from 5.23-22.73 (mean: 13.46), and LR ranged from 9.37-20.06 (mean: 12.8). The 2010 samples at SBR recorded 2.71-22.9 (mean: 9.84). Collected from LR, Ismail, and Safahieh [57] reported that $\mathrm{Cu}$ ranged from $11.3-92.8 \mathrm{mg} / \mathrm{kg}$, with $40-60 \%$ in both metals contributed by the nonresistant fractions related to anthropogenic sources.

When comparing to the SGQ values (Table S3), all Cu levels were below those by Chapman et al. [8], Macdonald et al. [23], and Long et al. [22]. Compared to the reference background values (Table S3), the mean Cu levels from the three rivers from the 2007 and 2010 samples were higher than the background $\mathrm{Cu}$ level by Yap et al. [31].

Based on sediments collected in 1998, Saed et al. [58] reported that the $\mathrm{Cu}$ range was $100-574 \mathrm{mg} / \mathrm{kg}$, while in the Sepang Kecil River, the concentrations ranged from $51.2-57.9 \mathrm{mg} / \mathrm{kg}$. Based on the oyster Isognomon alatus transplantation study, Saed et al. [58,60] showed that SBR had a higher level of $\mathrm{Cu}$ bioavailability than in the SKR. Based on the two sites near the river mouth at SBR, Saed et al. [58] reported Cu as 100-190 mg/kg dw.

After 5 years of PFB, the sediments near the river mouth of SBR, Cu levels were found to have a lower range (3.43-41.8 mg/ $\mathrm{kg} \mathrm{dw}$ ) based on samples from 2003 [6]. The $\mathrm{Cu}$ levels were continuing to be lower based on samples from $2003(5.23-22.73 \mathrm{mg} / \mathrm{kg} \mathrm{dw})$ and 2010 ( 2.71 to $22.9 \mathrm{mg} / \mathrm{kg} \mathrm{dw}$ ). This means that there had been 36.9 and 8.30 times lower $\mathrm{Cu}$ levels based on the ratios of minimum and maximum Cu levels from the 1998 and 2010 samples, respectively, after 12 years of PFB.

Most interesting, based on samples collected in 1996, Ismail and Ramli [5] reported the sites close to the pig farm area upstream of SBR contained elevated $\mathrm{Cu}$ levels (210-670 mg/kg dw). Later, Hossain et al. [61] also reported high $\mathrm{Cu}$ levels (213-518 $\mathrm{mg} / \mathrm{kg} \mathrm{dw}$ ) at the SBR upstream based on 1997 samples. Based on samples collected in 1998, Saed et al. [58] consistently reported high Cu levels (400 to $574 \mathrm{mg} / \mathrm{kg}$ $\mathrm{dw}$ ) at almost similar SBR upstream sampling sites near piggery farms. After 5 years of PFB, the sediments at Pelanduk River recorded a lower $\mathrm{Cu}$ range (66.6-136 mg/kg dw) based on samples collected in 2003 [6]. This means that there were 3.15 and 4.93 times lower $\mathrm{Zn}$ levels based on the minimum and maximum $\mathrm{Cu}$ levels ratios from the 1996 and 2003 samples, respectively.

In particular, at the estuary section of SBR, there has been a decline of $\mathrm{Cu}$ levels from 100-190, 3.43-41.8, 5.23-22.73, and 2.71-22.9 for samples from 1998, 2003, 2007, and 2010, respectively (Figure 5). In Figure 5, similarly, like Zn (Figure 2), we also used an exponential decay model because it can estimate the best plot with a decay constant $(\lambda)$ of $0.16(R=0.88$; $p<0.05)$, to summarize the negative relationship between $\mathrm{Cu}$ levels and years after the PFB. Likewise, this exponential regression can also model a situation of a faster decrement of $\mathrm{Cu}$ levels in the estuary of SBR sediments in the first few years after the PFB and a lower decrement after 12 years of PFB in 2010. 


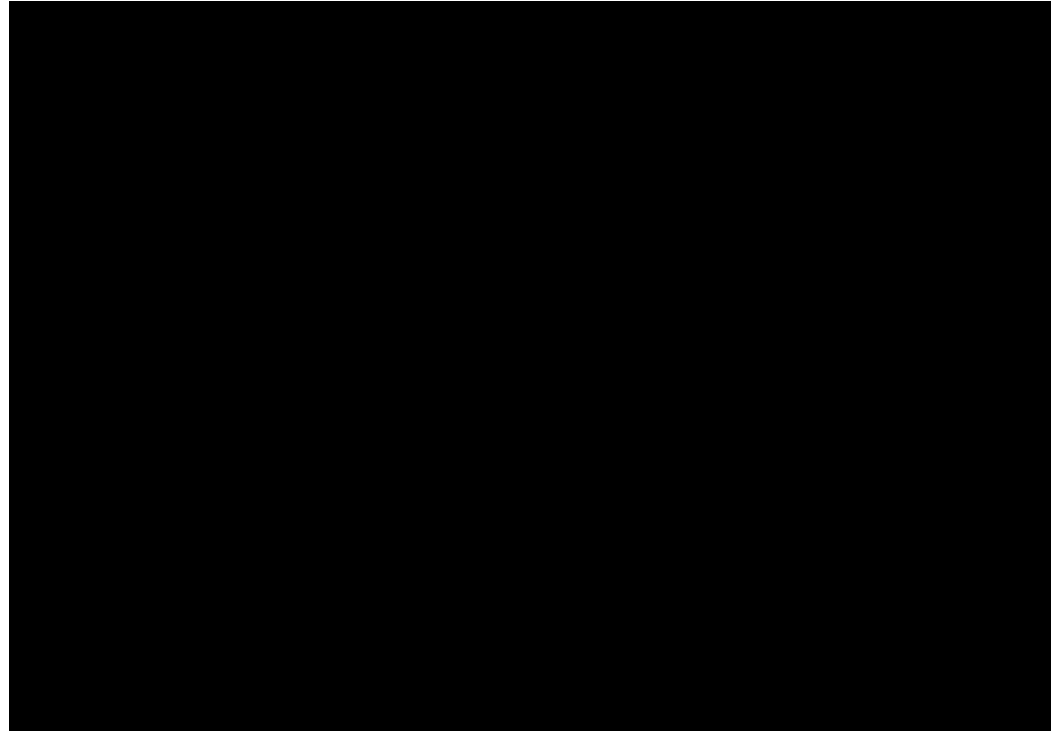

Figure 5. Decreasing Cu concentrations ( $\mathrm{mg} / \mathrm{kg}$ dry weight) in the surface sediments from the river mouth of Sepang Besar River in the samples from 1996 (Ismail and Ramli, 1997), 1997 (Hossain et al., 2001), 1998 (Saed et al., 2002), 2003 (5 years after the piggery farm ban) (Yap et al., 2007), 2007 (9 years after the piggery farm ban) (present study), and 2010 (12 years after the piggery farm ban) (present study). The line on the maximum values is based on an exponential equation.

The distributions of four geochemical fractions of $\mathrm{Cu}$ in all the sampling sites from the present study are shown in Figure 6. The Bio fraction for $\mathrm{Cu}$ ranged from $0.77-1.27 \%$ (mean: $1.12 \%$ ) for LR, $1.12-6.11 \%$ (mean: 2.54 ) for SBR, and 1.63-3.44\% (mean: $2.31 \%$ ) for SKR. The NonBio fraction for $\mathrm{Cu}$ ranged from 98.69-99.19\% (mean: 98.86\%) for LR, 93.89-98.82\% (mean: 97.44\%) for SBR, and 96.56-98.48\% (mean: 97.70\%) for SKR. These results indicated that the non-Bio fraction dominated the total $\mathrm{Cu}$ concentrations by more than $9 \%$ in the three rivers.

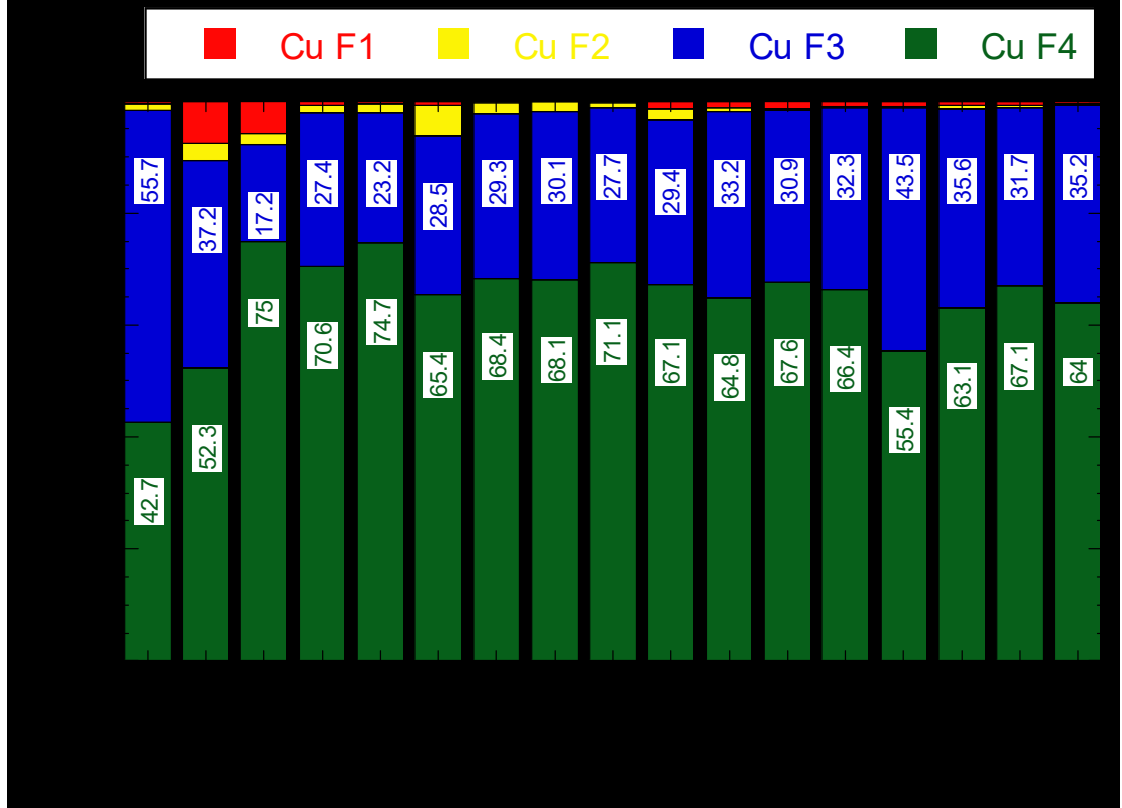

Figure 6. Distributions (\%) of four geochemical fractions (F1 = EFLE; F2 = acid-reducible; F3 = Oxidisable-organic; F4 = resistant) of $\mathrm{Cu}$ in all the sampling sites from Sepang Besar River (SBR), Sepang Kecil River (SKR), and Lukut River (LR) in the samples from the 2007 and 2010 (indicated by *). 
For $\mathrm{Cu}$ ICF, the values ranged from 0.49-0.81 (mean: 0.59) for LR, 0.34-0.53 (mean: 0.44 ) for SBR, and 0.48-0.54 (mean: 0.50) for SKR. For Cu RAC, the values ranged from 0.48-0.98\% (mean: $0.77 \%$ ) for LR, $0.12-0.69 \%$ (mean: $0.44 \%$ ) for SBR, and $1.15-1.52 \%$ (mean: $1.39 \%$ ) for SKR. All the values indicated that LR and SBR are classified as 'no risk' while SKR was classified as 'low risk' of $\mathrm{Cu}$.

The ranges of $\mathrm{Cu}$ ER values for all the sampling sites from the present study ranged from 0.95-8.03 and 3.82-32.35 for ER-1 and ER-2, respectively (Figure 7). According to Hakanson's [40] classification, they were in the category of 'minimal potential ecological risk $(\mathrm{ER}<40)^{\prime}$.
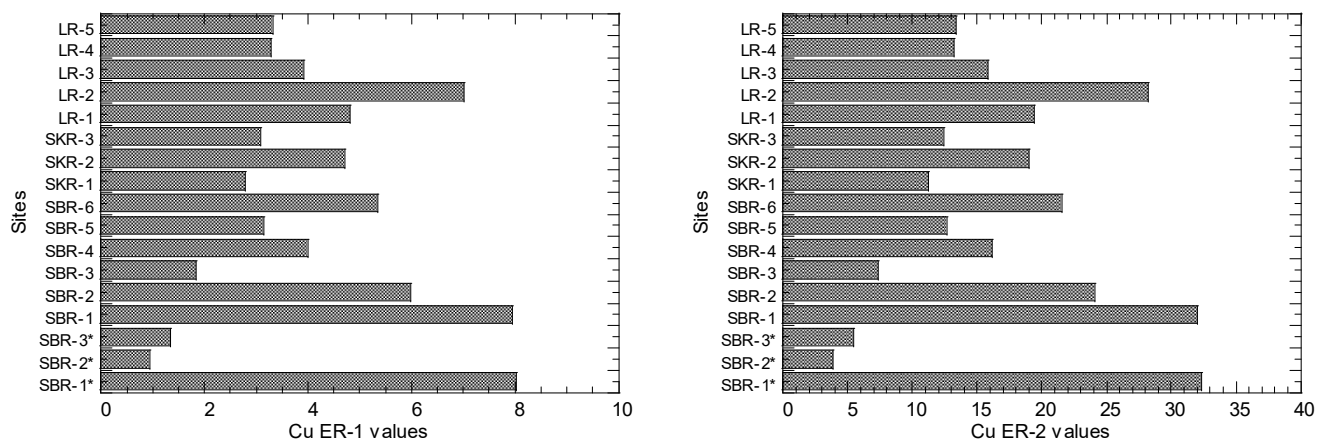

Figure 7. Ecological risk (ER) values of $\mathrm{Cu}$ in all the sampling sites from Sepang Besar River (SBR), Sepang Kecil River (SKR), and Lukut River (LR) in the samples from the 2007 and 2010 (indicated by *). The background used was based on background values by Wedepohl [37] (indicated by ER-1) and Malaysian studies (indicated by ER-2).

The HHRA results, due to $\mathrm{Cu}$ exposure in the surface sediments from the three rivers, are shown in Table S8. For children $\mathrm{Cu}$, based on the mean values of rivers from the 2007 and 2010 samples, the $\mathrm{HQ}_{\text {ing }}$ values ranged from $8.88 \times 10^{-4}$ to $7.53 \times 10^{-3}$, the $\mathrm{HQ}_{\mathrm{der}}$ values ranged from $4.74 \times 10^{-6}$ to $4.01 \times 10^{-5}$, while $\mathrm{HQ}_{\mathrm{inh}}$ values ranged from $2.42 \times 10^{-8}$ to $2.05 \times 10^{-7}$. The children's HI ranged from $8.93 \times 10^{-4}$ to $7.57 \times 10^{-3}$. For adult $\mathrm{Cu}$, based on the mean values of rivers from the 2007 and 2010 samples, the HQing values ranged from $1.19 \times 10^{-4}$ to $1.01 \times 10^{-3}$, the $\mathrm{HQ}_{\mathrm{der}}$ values ranged from $1.21 \times 10^{-5}$ to $1.03 \times 10^{-4}$, while $\mathrm{HQ}_{\text {inh }}$ values ranged from $1.09 \times 10^{-8}$ to $9.23 \times 10^{-8}$. The adult $\mathrm{HI}$ ranged from $1.31 \times 10^{-4}$ to $1.11 \times 10^{-3}$.

Based on the maximum $\mathrm{Cu}$ HI values in both children and adults (Table S8), all three Cu pathways followed SBR1 $>$ SBR2 $>$ SBR3 $>$ SKR5 $>$ LR4 $>$ SBR2 $>$ SBR2010 > SBR2007 $>$ LR2007 > SKR2007. With all the HI values found below 1 in both children and adults, the estuary sediments from the three rivers would pose a non-unhealthy NCR risk of $\mathrm{Cu}$. It was shown that the three different exposure pathways of $\mathrm{Cu}$ for children and adults diminished in the following order: ingestion $>$ dermal contact $>$ inhalation. This agreed with that reported by Yap et al. [59] based on the soils collected from six land uses in Peninsular Malaysia.

\section{3. $\mathrm{Pb}$}

Table 99 shows the concentrations of total $\mathrm{Pb}$, percentages of four geochemical fractions, percentages of bioavailable fraction (Bio), and a non-bioavailable fraction (NonBio), $\mathrm{ICF}$, and $\mathrm{RAC}$ for $\mathrm{Pb}$. Based on sediments collected from Sepang Besar River in December 2007, for Pb, SKR ranged from 20.02-32.47 (mean: 25.3), SBR ranged from 18.99-41.25 (mean: 28.26), and LR ranged from 28.93-47.37 (mean: 40.33). The Zn levels in 2010 samples at SBR ranged from 25.61-31.99 (mean: 28.78).

When comparing to the SGQ values (Table S3), all mean Pb levels were below those by Chapman et al. [8], Macdonald et al. [23], and Long et al. [22]. When compared to the reference background values (Table S3), the mean $\mathrm{Pb}$ levels from the three rivers from 
the 2007 and 2010 samples were higher than the background Pb levels by Taylor and McLennan [62], Rudnick and Gao [63], Wedepohl [37], and Yap and Noorhaidah [38].

Based on sediments collected in 1998, Saed et al. [58] reported that the $\mathrm{Pb}$ range was $14.90-51.2 \mathrm{mg} / \mathrm{kg}$ dw in Sepang Besar River, while in the Sepang Kecil River, the concentration ranged from 6.97-9.44 mg/kg dw. Ismail and Ramli [5] reported $\mathrm{Pb}$ as $3.4-46.5 \mathrm{mg} / \mathrm{kg}$ $\mathrm{dw}$. Based on the oyster Isognomon alatus transplantation study, Saed et al. [58,60] showed that SBR had a higher level of Pb bioavailability than in the SKR.

However, it should be noted that the sampling sites as reported by Saed et al. [58] in SBR covered the first two sites near the river mouth, which was relevant and comparable to the present study. All the sampling sites at SBR from the present study covered the river mouth section. Therefore, based on the two sites near the river mouth at SBR by Saed et al. [58], they reported $\mathrm{Pb}$ as $15-28 \mathrm{mg} / \mathrm{kg} \mathrm{dw}$.

In particular, at the estuary section of SBR, the $\mathrm{Pb}$ ranges were still below $50.0 \mathrm{mg} / \mathrm{kg}$ dw for samples from 1996, 1998, 2007, and 2010, respectively. However, there was no significant difference in Pb levels from 1996 to 2010 (Figure 8). This could be because $\mathrm{Pb}$ was not a piggery farming effluent source before PFB in 1998, judging that the maximum $\mathrm{Pb}$ levels were lower than most of the SQGs (Table S3). In Figure 8, we used an exponential regression model, following that for $\mathrm{Zn}$ and $\mathrm{Cu}$ (Figures 2 and 5). Clearly, there is no significant change with a low positive constant $(\lambda)$ of $0.01(R=0.55 ; p>0.05)$ for the $\mathrm{Pb}$ levels from 1996 to 2010.

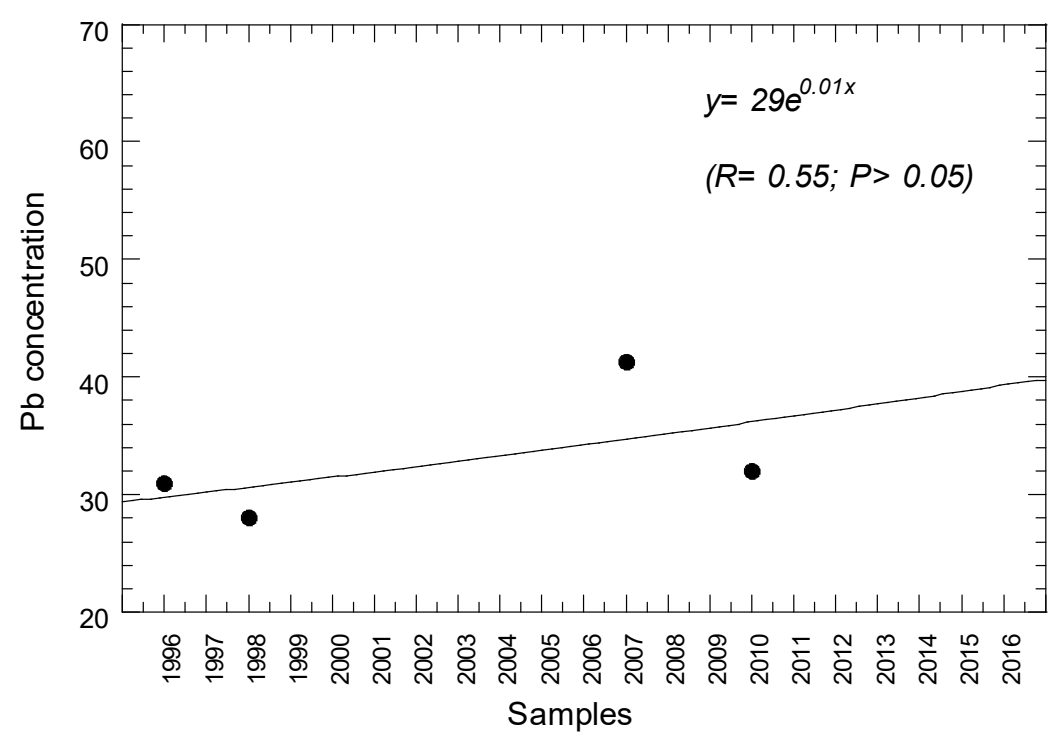

Figure 8. Decreasing $\mathrm{Pb}$ concentrations ( $\mathrm{mg} / \mathrm{kg}$ dry weight) in the surface sediments from Sepang Besar River estuary in the samples from 1996 (Ismail and Ramli, 1997), 1998 [58], 2007 (9 years after the piggery farm ban) (present study), and 2010 (12 years after the piggery farm ban) (present study). The line on the maximum values is based on an exponential equation.

The distributions of four geochemical fractions of $\mathrm{Pb}$ in all the sampling sites from the present study are shown in Figure 9. The Bio fraction for $\mathrm{Pb}$ ranged from 3.07-8.57\% (mean: $4.91 \%$ ) for LR, $4.86-28.87 \%$ (mean: 11.67) for SBR, and 5.63-8.56\% (mean: 6.68\%) for SKR. The NonBio fraction for Pb ranged from 91.43-96.93\% (mean: 95.09\%) for LR, 71.13-95.09\% (mean: $88.32 \%$ ) for SBR, and $91.38-94.37 \%$ (mean: $93.27 \%$ ) for SKR. These results indicated that the NonBio fraction dominated the total $\mathrm{Pb}$ concentrations by more than $50 \%$ in the three rivers. 


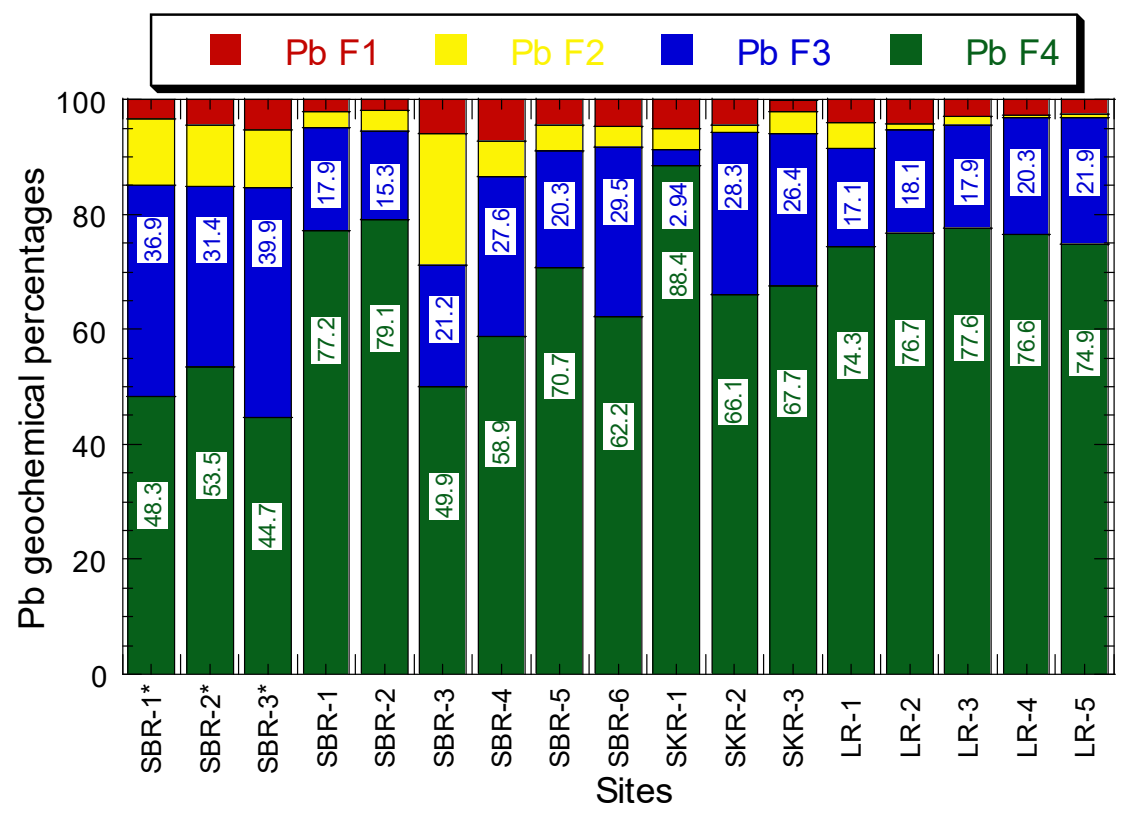

Figure 9. Distributions (\%) of four geochemical fractions (F1 = EFLE; F2 = acid-reducible; F3 = Oxidisable-organic; F4 = resistant) of $\mathrm{Pb}$ in all the sampling sites from Sepang Besar River (SBR), Sepang Kecil River (SKR), and Lukut River (LR) in the samples from the 2007 and 2010 (indicated by ${ }^{*}$ ).

For $\mathrm{Pb}$ ICF, the values ranged from 0.29-0.35 (mean: 0.32) for LR, 0.26-1.00 (mean: 0.55 ) for SBR, and 0.13-0.51 (mean: 0.37) for SKR. For Pb RAC, the values ranged from $2.43-4.21 \%$ (mean: $3.28 \%$ ) for LR, $1.78-7.21 \%$ (mean: $4.33 \%$ ) for SBR, and $1.90-5.00 \%$ (mean: $3.81 \%$ ) for SKR. All the values indicated that the three rivers are classified as 'low risk' for $\mathrm{Pb}$.

The ranges of $\mathrm{Pb}$ ER values for all the sampling sites from the present study ranged from 5.59-13.93 and 4.87-12.16 for ER-1 and ER-2, respectively (Figure 10). According to Hakanson's [40] classification, they were in the category of 'minimal potential ecological risk $(\mathrm{ER}<40)^{\prime}$.
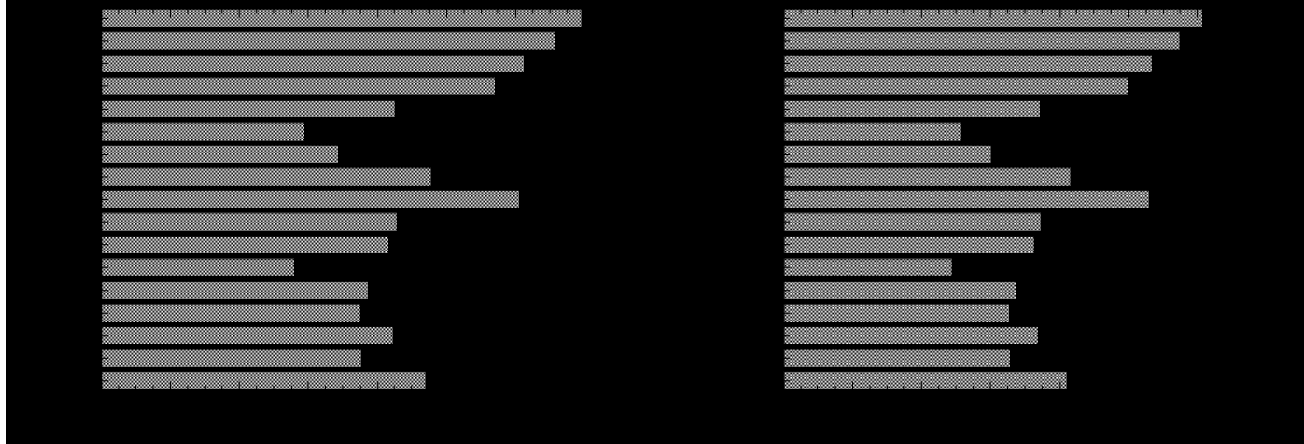

Figure 10. Ecological risk (ER) values of $\mathrm{Pb}$ in all the sampling sites from Sepang Besar River (SBR), Sepang Kecil River (SKR), and Lukut River (LR) in the samples from the 2007 and 2010 (indicated by *). The background used was based on background values by Wedepohl [37] (indicated by ER-1) and Malaysian studies (indicated by ER-2).

The HHRA results due to $\mathrm{Pb}$ exposure in the surface sediments from the three rivers are shown in Table S10. For children $\mathrm{Pb}$, based on the mean values of rivers from the 2007 and 2010 samples, the $\mathrm{HQ}_{\text {ing }}$ values ranged from $7.03 \times 10^{-2}$ to $1.75 \times 10^{-1}$, the $\mathrm{HQ}_{\text {der }}$ values ranged from $7.59 \times 10^{-4}$ to $1.89 \times 10^{-3}$, while $\mathrm{HQ}_{\text {inh }}$ values ranged from $1.94 \times 10^{-6}$ to $4.83 \times 10^{-6}$. The children's HI ranged from $7.11 \times 10^{-2}$ to $1.77 \times 10^{-1}$. For 
adult $\mathrm{Pb}$, based on the mean values of rivers from the 2007 and 2010 samples, the $\mathrm{HQ}_{\text {ing }}$ values ranged from $9.43 \times 10^{-3}$ to $2.35 \times 10^{-2}$, the $\mathrm{HQ}_{\mathrm{der}}$ values ranged from $1.94 \times 10^{-3}$ to $4.83 \times 10^{-3}$, while $\mathrm{HQ}_{\text {inh }}$ values ranged from $8.71 \times 10^{-7}$ to $2.17 \times 10^{-6}$. The adult $\mathrm{HI}$ ranged from $1.14 \times 10^{-2}$ to $2.84 \times 10^{-2}$.

Based on the maximum $\mathrm{Pb} \mathrm{HI}$ values in both children and adults (Table S10), all three $\mathrm{Pb}$ pathways followed SBR2 > LR2007 > SBR1 > SBR2007 > SKR2007 > SBR2010 > SKR2. With all the HI values found below 1 in both children and adults, the estuary sediments of the three rivers would pose a non-unhealthy $\mathrm{NCR}$ of $\mathrm{Pb}$. It was shown that the three different exposure pathways of $\mathrm{Pb}$ for children and adults diminished in the following order: ingestion $>$ dermal contact $>$ inhalation. This agreed with the report by Yap et al. [59] based on the soils collected from 6 land uses in Peninsular Malaysia.

\subsection{Potential Ecological Risk Index}

The values of PERI based on ER values of $\mathrm{Cu}, \mathrm{Pb}$, and $\mathrm{Zn}$ at all sampling sites in the mangrove sediments are shown in Figure 11. The values ranged from 7.76-19.98 and 11.51-44.81 for PERI-1 and PERI-2, respectively. They were denoted as 'minimal ecological risk $(\mathrm{PERI}<150)^{\prime}[40]$ from the combination of all three ER values of $\mathrm{Cu}, \mathrm{Pb}$, and $\mathrm{Zn}$.
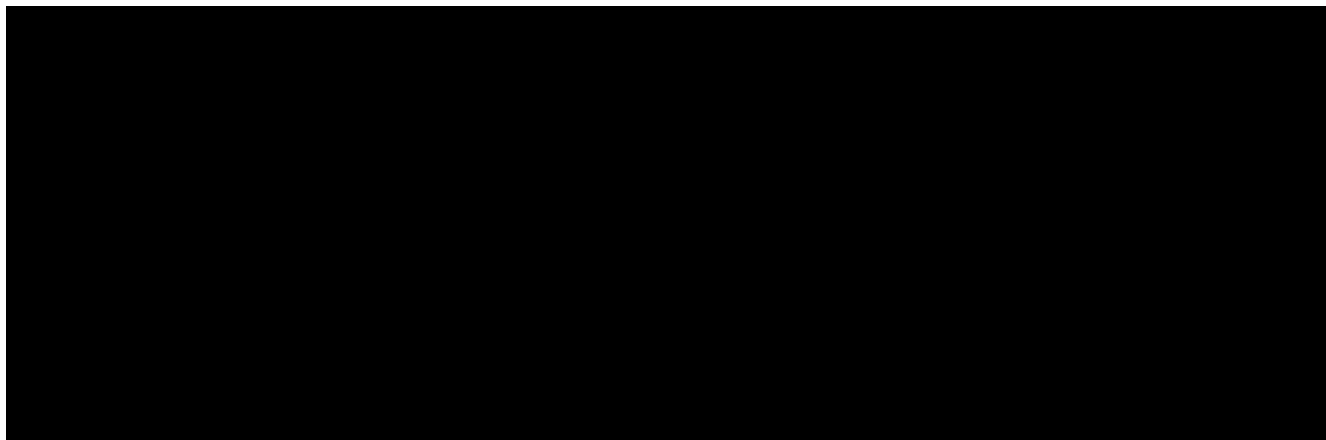

Figure 11. Values of potential ecological risk index (PERI) based on the ecological risk of $\mathrm{Cu}, \mathrm{Pb}$, and $\mathrm{Zn}$ at all sampling sites in the mangrove sediments collected from Lukut River (LR), Sepang Besar River (SBR), and Sepang Kecil River (SKR) in 2007 except those indicated by * which was collected in 2010. The background used was based on background values by Wedepohl [37] (indicated by PERI-1) and Malaysian studies (indicated by PERI-2).

Based on the estuary of SBR, it should be noted that samples from 1996 and 1998 indicated PERI-1 values of 79.5-83.5, which were categorized as 'minimal ecological risk (PERI < 150)' [40]. The PERI-2 values of 294-307 were categorized as 'considerable ecological risk' (300 $\leq$ PERI < 600) [40]. There were distinct decreasing PERI values in the surface sediments of SBR in the samples from 1996 [5], 1998 [58], 9 and 12 years after the PFB in 2007 and 2010, respectively (Figure 12). According to RAC values, all the PTMs were associated with low risk levels. Therefore, they can hardly enter the food chain and pose serious threats for aquatic and benthic organisms.

As illustrated by the plots in Figure 12, the exponential decay model shows that the PERI values become rapidly lower with increasing years of PFB. These two plots show decrement of PERI values for decay constants $(\lambda)$ of $0.12(R=0.98, p<0.05)$ and 0.16 $(R=0.97 ; p<0.05)$ for PERI-1 and PERI-2 values, respectively. The confident limits of these decay constants are high with the high $R$ values. Therefore, based on the PERI-2 value, we have reason to believe that the decrement indicated that the ecological risks of PTMs have improved from 'considerable ecological risk' to 'minimal ecological risk' [40]. This is a more conclusive model since it included the three metals with a single value. 

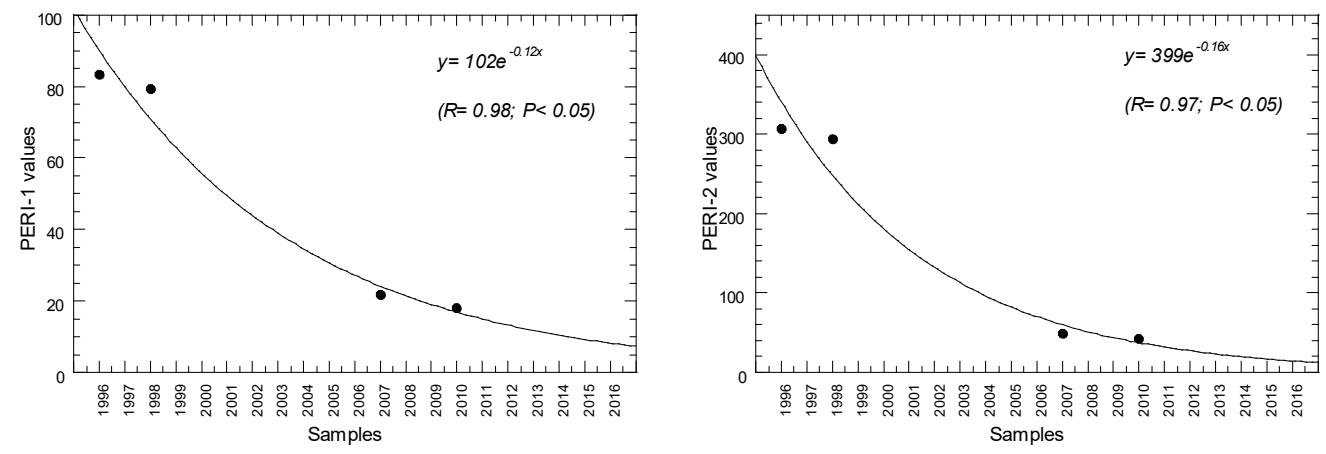

Figure 12. Decreasing PERI values (based on $\mathrm{Cu}, \mathrm{Pb}$, and $\mathrm{Zn}$ ) in the surface sediments from Sepang Besar River estuary in the samples from 1996 (Ismail and Ramli, 1997), 1998 (Saed et al., 2002), 2007 (9 years after the piggery farm ban) (present study), and 2010 (12 years after the piggery farm) (present study). The background used was based on background values by Wedepohl [37] (indicated by PERI-1) and Malaysian studies (indicated by PERI-2). The equations are based on the exponential equation.

\section{Discussion}

All the sampling sites at SBR showed Zn ICF values with 'moderate contamination'; $\mathrm{Cu}$ and $\mathrm{Pb}$ ICF values with 'low contamination' [35]. This may reveal a high retention time with low mobility and high stability of $\mathrm{Zn}, \mathrm{Cu}$, and $\mathrm{Pb}$ because of the difficulty being released into the environment and therefore possess a low risk to aquatic life $[64,65]$.

The lower levels of $\mathrm{Cu}$ and $\mathrm{Zn}$ could be due to the closure of the pig farm operation in 1998 [66] because $\mathrm{Cu}$ and $\mathrm{Zn}$ were known and reported to be contributed by pig farming operations. Many previous studies have suggested that pig farm effluents significantly contribute to the elevation of sediment $\mathrm{Cu}$ and $\mathrm{Zn}$ concentration at other rivers in Malaysia [5]. $\mathrm{Cu}$ and $\mathrm{Zn}$ are commonly added into the pigs' fodder to prevent parasites infestation. The introduction of a high concentration of $\mathrm{Cu}$ and $\mathrm{Zn}$ into the pig's diet could also act as a growth promoter [67-69].

Pig farm activities are the most probable contributor to the elevation of $\mathrm{Cu}$ and $\mathrm{Zn}$ levels in sediment in the region. Another study has also uncovered that pig slurry could likely induce the pollution of $\mathrm{Cu}$ and $\mathrm{Zn}[54,70,71]$. Several other findings have also agreed that frequent utilization of pig slurries could result in the accumulation of $\mathrm{Cu}$ and $\mathrm{Zn}$ in the soil [72,73].

Bo et al. [73] reported that in 10 provinces of China, 100\% of the pig feed samples were over the national standard for $\mathrm{Cu}$ (13.2 49.0 times of the standard), while for $\mathrm{Zn}$ concentrations, the pig feeds were 1.3 9.5 times the national standard. There were significant $(p<0.01)$ positive correlations for $\mathrm{Cu}$ and $\mathrm{Zn}$ between pig manures and feeds. Suppose the manure was applied to land in these provinces at the current rate. Additionally, the concentrations of $\mathrm{Cu}$ and $\mathrm{Zn}$ in soils in Beijing would exceed the standards in 65 and 51 years, respectively, while in Tianjin, the soil standards for $\mathrm{Cu}$ and $\mathrm{Zn}$ would be exceeded in 53 and 91 years, respectively. This analysis suggested that it was essential to control the rates of pig manure application in agriculture and reduce the amounts of $\mathrm{Cu}$ and $\mathrm{Zn}$ in pig feeds.

Zhu et al. [67] reported the elevated levels of $\mathrm{Cu}$ and $\mathrm{Zn}$ in pig manure and feed samples from 64 pig farms in different regions of Shannxi Province, China (Cu: $38.3-806 \mathrm{mg} / \mathrm{kg}$ and Zn: $90.69-1208.19 \mathrm{mg} / \mathrm{kg}$ in feeds, and Cu: 78.9-1543 mg/kg and Zn: $68.7-3012 \mathrm{mg} / \mathrm{kg}$ in manure). They also reported that the maximum concentrations of $\mathrm{Cu}, \mathrm{Zn}$, and $\mathrm{Pb}$ in pig feeds were 5.44, 34.3, and 10.9 times higher than the Chinese national standards limits. Zhang et al. [68] reported that the annual output of effluents from pig farms was the most important factor correlated with the nutrients and heavy metals in soils.

$\mathrm{Cu}$ and $\mathrm{Zn}$ are often added to feed in concentrations much higher than those needed by the animal (to avoid deficiency) to benefit from their protective effects against digestive pathologies [71]. Supplementation of trace metals is helpful during the postweaning phase, 
but not beyond, and the addition of microbial phytase in feed improves the availability of zinc for the animal [74]. Based on the pig slurries of 36 pig farms in South-eastern Spain, Moral et al. [69] reported that $\mathrm{Cu}$ and $\mathrm{Zn}$ were highly accumulated in the soils with pig slurries' application (4 and $15 \mathrm{~kg} /$ ha/year, respectively).

Based on a fish biodiversity study in SBR, conducted in 2014, Ya et al. [75] reported that the indices of Shannon-Weiner and Margalef at the two sampling sites in the upstream of SBR (close to Rambai River and Pelanduk River) were 1.73-2.09 and 2.40-3.11, respectively, and were close to those indices (1.83-1.92, and 2.45-2.72, respectively) of the two sampling sites located at the estuaries of SBR. These biodiversity indices showed that the fish diversity at Sepang Besar estuary could be considered high, especially at the estuary of SBR (13-26 fish species). The results were comparable to those (Shannon-Wiener diversity index (1.98) and Margalef species richness index (3.24), based on 20 fish species) reported from one of the lower reaches of Ganjiang River (China) [76]. This indicated that fish biodiversity had been recovered since PFB in 1998. Based on the Department of Environment Malaysian [77], the Sepang River was classified as a 'slightly polluted' river based on the water quality status of 2009-2010. However, there have been no reports on the PTMs in the surface sediments in SBR. Therefore, the PTMs data provided in the present study is important information on the recovery of SBR after PFB on a scientific basis.

The present results have contributed to our understanding of the following issues. This is the first study assessing the ecological-health risks of PTMs in SBR, SKR, and LR in Selangor. The present study is not a mere monitoring study using surface sediments. This is also scientific evidence and a detailed assessment of the degree and pattern of PTMs $(\mathrm{Cu}$ and $\mathrm{Zn}$ ) decrement in the previously polluted SBR after years of PFB. The significance of monitoring PTMs in the sediments is beyond any reasonable doubt, judging from the many recent papers on this research monitoring studies (e.g., Wei et al. [78]; Hossain et al. [79]).

Dendievel et al. [80] proposed characterizing metal contamination trends from the 1960s by combining data from dated cores and subsurface sediments along the Rhône River (Switzerland-France). They also discovered hotspots caused by $\mathrm{Cu}$ and $\mathrm{Zn}$ leaching from vineyards, mining, and highway runoff. They found that the time it took for metal contamination in sediment to recover varied depending on the metal and that it took less time upstream (15-20 years) than downstream (30-40 years). Moore and Langner [81] (2021) studied the bed silt from a big river that had been contaminated by mining and smelting to see how fast metal concentrations naturally attenuated. They indicated that by using the natural decay model, average concentrations of five metals (including $\mathrm{Cu}, \mathrm{Pb}$, and $\mathrm{Zn}$ ) would take around 90 years to decline below "probable effects concentrations" in the most contaminated reaches. The above two investigations, however, were not based on the recovery of $\mathrm{Cu}$ and $\mathrm{Zn}$ from piggery wastes in river sediments. As a result, the current findings based on piggery wastes in SBR estuary sediments would be useful for future reference.

Recovery is largely reliant on source reduction and how close the metal levels close to the basin background metal concentration are, according to model simulations with various levels of remediation effectiveness [81]. By understanding the role of natural attenuation in restoration design and implementation, the current $\mathrm{Cu}$ and $\mathrm{Zn}$ decay models in SBR can provide insight into remediation procedures and ultimately reduce the cost of restoration.

From an economic point of view, the pig farm industry can be revived pending the excellent management of the water quality [82] and an effective constructed wetland system for wastewater treatment [83]. For example, Li et al. [84] recommended chemical leaching with EDTA, and the E-S mixture was highly efficient in removing $\mathrm{Cu}$ and $\mathrm{Zn}$ from pig manure.

A variety of measures and conservation strategies is essential, and conserving SME should be implemented at a local and national level. Even though the Sepang mangrove ecosystem (SME) is of high socio-economic importance, such as with the tourism industry (such as Sepang Gold Coast resort), surprisingly, there has been no available information on the resource or economic valuation in the SME like that reported for the Kuala Selangor 
mangrove ecosystem [85]. Getzner and Islam [86] recommended that the implementation of separate, original economic valuation studies of the mangrove ecosystem is needed.

This study has improved our understanding of how the previously polluted sediments at SBR by piggery farming effluents has declined to safe levels of $\mathrm{Cu}$ and $\mathrm{Zn}$ after 9 and 12 years of PFB, and it provides an additional weight of evidence for the linkages between PTMs' degree of pollution and livestock effluents that should not be repeated in the future. Further monitoring studies on ecological-health risks of PTMs in the sediments are necessary in case of a revival of the piggery farming activities at the SME.

The present provisional status of ecological-health risks of PTMs on the SBR estuary could serve as a platform for evaluating the economic valuation studies on the SME. This information is essential in determining appropriate strategies for conservation management in the SME. Such data would also help highlight the overall status of PTMs in the SME. Furthermore, a system that responds to real-time threats, such as illegal effluents from livestock, small-scale industries, and other land-based construction would also help implement conservation strategies before the disruption. Finally, the development of protected mangrove areas is also essential in preventing mangrove degradation in the SME.

\section{Conclusions}

The present findings indicated that the three estuaries had caused no ecological-health risks of $\mathrm{Cu}, \mathrm{Pb}$, and $\mathrm{Zn}$. The PTMs in the sediments from the three rivers' estuaries were lower than those of established SQGs. HHRA indicated that the three different exposure pathways of $\mathrm{Cu}, \mathrm{Pb}$, and $\mathrm{Zn}$ for children and adults decreased in the following order: ingestion $>$ dermal contact $>$ inhalation. In general, the $\mathrm{HI}$ values for $\mathrm{Cu}, \mathrm{Pb}$, and $\mathrm{Zn}$ in all sampling sites at the three estuaries were lower than 1 , indicating that there was no NCR of the three PTMs for children and adults. In particular, the SBR estuary had drastically lower levels of $\mathrm{Zn}$ and $\mathrm{Cu}$ after 9 and 12 years of PFB. Based on the exponential decay model, the PERI values showed that the estuary of SBR has been improved from a 'considerable ecological risk' to a 'minimal ecological risk' after 12 years of PFB. The present ecological-health risks of PTMs on the SBR estuary could provide a basis for evaluating the economic valuation studies on the SME. It is still recommended to investigate the current status of PTMs in the three rivers to ensure adopting adequate control measures in compliance with national and international regulations on the protection of the mangrove ecosystem in Malaysia.

Supplementary Materials: The following supporting information can be downloaded at: https: / / www.mdpi.com/article/10.3390/su14031525/s1, Table S1. Sampling information in the mangrove of Sepang Besar River (S1-S6), Sepang Kecil River (S7-S9) and Lukut River (L1-L5). Samplings were conducted on 1 December 2007, except for * on 5 May 2010, Table S2. Heavy metals analysis recovery percentages of the certified reference materials (CRM), Table S3. Comparisons between surface sediments from this study with those cited from sediment quality guidelines, and reference values, Table S4. Definition, exposure factors, and reference values were used to estimate the intake values and health risks of potentially toxic metals in sediments collected from Peninsular Malaysia, Table S5. Concentrations (mg/kg dry weight) of total Zn, percentages of four geochemical fractions (F1, F2, $\mathrm{Fe}$, and F4), percentages of bioavailable fraction (Bio) and a non-bioavailable fraction (NonBio), Individual contamination factors (ICF), and risk assessment code (RAC), for $\mathrm{Zn}$ of surface sediments in Lukut River (LR), Sepang Besar River (SBR) and Sepang Kecil River (SKR) mangrove ecosystems, based on nonresistant fraction as reference fraction or normalizer $(-1)$, and based on background levels of the metals as reference metal or normalizer that were reported from Peninsular Malaysia $(-2)$, Table S6. Overall statistics of values of hazard quotient (HQ), and hazard index (HI), in the three exposure routes (ingestion $=\mathrm{HQ}_{\text {ing }}$; inhalation $=\mathrm{HQ}_{\mathrm{inh}}$; dermal contact $=\mathrm{HQ}_{\mathrm{der}}$ ) of $\mathrm{Zn}$, for both children (C) and adults (A) in the mangrove sediments collected from Lukut River (LR), Sepang Besar River (SBR) and Sepang Kecil River (SKR), Table S7. Concentrations ( $\mathrm{mg} / \mathrm{kg}$ dry weight) of total $\mathrm{Cu}$, percentages of four geochemical fractions (F1, F2, Fe, and F4), percentages of bioavailable fraction (Bio) and a non-bioavailable fraction (NonBio), Individual contamination factors (ICF), and risk assessment code (RAC), for Cu of surface sediments in Lukut River (LR), Sepang Besar River 
(SBR) and Sepang Kecil River (SKR) mangrove ecosystems, based on nonresistant fraction as reference fraction or normalizer $(-1)$, and based on background levels of the metals as reference metal or normalizer that were reported from Peninsular Malaysia (-2), Table S8. Overall statistics of values of hazard quotient $(\mathrm{HQ})$, hazard index $(\mathrm{HI})$, and carcinogenic risk $\left(\mathrm{CR}_{\mathrm{inh}}\right)$ in the three exposure routes (ingestion $=\mathrm{HQ}_{\mathrm{ing}}$; inhalation $=\mathrm{HQ}_{\mathrm{inh}}$; dermal contact $\left.=\mathrm{HQ}_{\mathrm{der}}\right)$ of $\mathrm{Cu}$, for both children $(\mathrm{C})$ and adults (A) in the mangrove sediments collected from Lukut River (LR), Sepang Besar River (SBR) and Sepang Kecil River (SKR), Table S9. Concentrations ( $\mathrm{mg} / \mathrm{kg}$ dry weight) of total $\mathrm{Pb}$, percentages of bioavailable fraction (Bio) and non-bioavailable fraction (NonBio), individual contamination factors (ICF), and risk assessment code (RAC), for Pb of surface sediments in Lukut River (LR), Sepang Besar River (SBR) and Sepang Kecil River (SKR) mangrove ecosystems, based on nonresistant fraction as reference fraction or normalizer ( -1$)$, and based on background levels of the metals as reference metal or normalizer that were reported from Peninsular Malaysia (-2), Table S10. Overall statistics of values of hazard quotient $(\mathrm{HQ})$, hazard index $(\mathrm{HI})$, carcinogenic risk $\left(\mathrm{CR}_{\mathrm{inh}}\right)$ in the three exposure routes (ingestion $=\mathrm{HQ}_{\text {ing }}$; inhalation $=\mathrm{HQ}_{\text {inh }}$; dermal contact $=\mathrm{HQ}_{\mathrm{der}}$ ) of $\mathrm{Pb}$, for both children $(\mathrm{C})$ and adults (A) in the mangrove sediments collected from Lukut River (LR), Sepang Besar River (SBR) and Sepang Kecil River (SKR).

Author Contributions: Conceptualization, C.K.Y. and K.A.A.-M.; methodology and validation, C.K.Y. and K.A.A.-M.; formal analysis, C.K.Y.; investigation, C.K.Y.; resources, K.A.A.-M.; data curation, C.K.Y.; writing-original draft preparation, C.K.Y.; writing — review and editing, C.K.Y. and K.A.A.-M. All authors have read and agreed to the published version of the manuscript.

Funding: This research received no external funding.

Institutional Review Board Statement: Not applicable.

Informed Consent Statement: Not applicable.

Data Availability Statement: Not applicable.

Acknowledgments: The authors would like to thank Koe Wei Wong for checking the citation numberings throughout the text by using Zotero, and the undergraduate students for providing the metal data.

Conflicts of Interest: The authors declare no conflict of interest.

\section{References}

1. Suit-B, Y.; Hassan, L.; Krauss, S.E.; Ooi, P.T.; Ramanoon, S.Z.; Yasmin, A.R.; Epstein, J.H. Mental Model of Malaysian Pig Farmers in Implementing Disease Prevention and Control Practices. Front. Vet. Sci. 2021, 8, 1337. [CrossRef] [PubMed]

2. Singh, S. 1998 Ban on Pig Farming in Bukit Pelanduk Still in Force. The Star. 2014. Available online: https://www.thestar.com. my/news/nation/2014/07/03/1998-ban-on-pig-farming-in-bukit-pelanduk-still-in-force/ (accessed on 20 December 2021).

3. Mohd Nor, M.N.; Gan, C.H.; Ong, B.L. Nipah Virus Infection of Pigs in Peninsular Malaysia. Rev. Sci. Tech. Int. Off. Epizoot. 2000, 19, 160-165. [CrossRef] [PubMed]

4. Chang, Y.O. Bukit Pelandok Revisited. Available online: https://www.theborneopost.com/2018/05/27/bukit-pelandokrevisited/ (accessed on 27 November 2021).

5. Ismail, A.; Ramli, R. Trace Metals in Sediments and Molluscs from an Estuary Receiving Pig Farms Effluent. Environ. Technol. 1997, 18, 509-515. [CrossRef]

6. Yap, C.K.; Ismail, A.; Ching, H.L.; Tan, S. Interpretation of Copper and Zinc Contamination in the Aquatic Environment of Peninsular Malaysia with Special Reference to a Polluted River, Sepang River. Wetl. Sci. 2007, 5, 311-321.

7. Astatkie, H.; Ambelu, A.; Mengistie, E. Contamination of Stream Sediment with Heavy Metals in the Awetu Watershed of Southwestern Ethiopia. Front. Earth Sci. 2021, 9, 609. [CrossRef]

8. Chapman, P.M.; Allard, P.J.; Vigers, G.A. Development of Sediment Quality Values for Hong Kong Special Administrative Region: A Possible Model for Other Jurisdictions. Mar. Pollut. Bull. 1999, 38, 161-169. [CrossRef]

9. Lafabrie, C.; Pergent, G.; Kantin, R.; Pergent-Martini, C.; Gonzalez, J.-L. Trace Metals Assessment in Water, Sediment, Mussel and Seagrass Species-Validation of the Use of Posidonia Oceanica as a Metal Biomonitor. Chemosphere 2007, 68, 2033-2039. [CrossRef]

10. Liu, J.; Xu, Y.; Cheng, Y.; Zhao, Y.; Pan, Y.; Fu, G.; Dai, Y. Occurrence and Risk Assessment of Heavy Metals in Sediments of the Xiangjiang River, China. Environ. Sci. Pollut. Res. Int. 2017, 24, 2711-2723. [CrossRef]

11. Algül, F.; Beyhan, M. Concentrations and Sources of Heavy Metals in Shallow Sediments in Lake Bafa, Turkey. Sci. Rep. 2020, 10, 11782. [CrossRef]

12. Förstner, U.; Wittmann, G.T.W. Metal Pollution in the Aquatic Environment; Springer Study Edition; Springer: Berlin/Heidelberg, Germany, 1981; ISBN 978-3-642-69385-4. 
13. Pachana, K.; Wattanakornsiri, A.; Nanuam, J. Heavy Metal Transport and Fate in the Environmental Compartments. Naresuan Univ. Sci. J. 2010, 7, 1-11.

14. Hill, N.A.; Simpson, S.L.; Johnston, E.L. Beyond the Bed: Effects of Metal Contamination on Recruitment to Bedded Sediments and Overlying Substrata. Environ. Pollut. Barking Essex 2013, 173, 182-191. [CrossRef] [PubMed]

15. Varol, M.; Şen, B. Assessment of Nutrient and Heavy Metal Contamination in Surface Water and Sediments of the Upper Tigris River, Turkey. Catena 2012, 92, 1-10. [CrossRef]

16. Adams, W.J.; Kimerle, R.A.; Barnett, J.W. Sediment Quality and Aquatic Life Assessment. Environ. Sci. Technol. 1992, 26, 1864-1875. [CrossRef]

17. Yan, N.; Liu, W.; Xie, H.; Gao, L.; Han, Y.; Wang, M.; Li, H. Distribution and Assessment of Heavy Metals in the Surface Sediment of Yellow River, China. J. Environ. Sci. 2016, 39, 45-51. [CrossRef] [PubMed]

18. MacFarlane, G.; Koller, C.; Blomberg, S. Accumulation and Partitioning of Heavy Metals in Mangroves: A Synthesis of Field-Based Studies. Chemosphere 2007, 69, 1454-1464. [CrossRef] [PubMed]

19. Qiu, Y.-W.; Yu, K.-F.; Zhang, G.; Wang, W.-X. Accumulation and Partitioning of Seven Trace Metals in Mangroves and Sediment Cores from Three Estuarine Wetlands of Hainan Island, China. J. Hazard. Mater. 2011, 190, 631-638. [CrossRef]

20. Bodin, N.; N’Gom-Kâ, R.; Kâ, S.; Thiaw, O.T.; Tito de Morais, L.; Le Loc’h, F.; Rozuel-Chartier, E.; Auger, D.; Chiffoleau, J.-F. Assessment of Trace Metal Contamination in Mangrove Ecosystems from Senegal, West Africa. Chemosphere 2013, 90, 150-157. [CrossRef]

21. Aljahdali, M.O.; Alhassan, A.B. Ecological Risk Assessment of Heavy Metal Contamination in Mangrove Habitats, Using Biochemical Markers and Pollution Indices: A Case Study of Avicennia Marina L. in the Rabigh Lagoon, Red Sea. Saudi J. Biol. Sci. 2020, 27, 1174-1184. [CrossRef]

22. Long, E.R.; Macdonald, D.D.; Smith, S.L.; Calder, F.D. Incidence of Adverse Biological Effects within Ranges of Chemical Concentrations in Marine and Estuarine Sediments. Environ. Manag. 1995, 19, 81-97. [CrossRef]

23. Macdonald, D.D.; Carr, R.S.; Calder, F.D.; Long, E.R.; Ingersoll, C.G. Development and Evaluation of Sediment Quality Guidelines for Florida Coastal Waters. Ecotoxicology 1996, 5, 253-278. [CrossRef]

24. Bianchi, T.S. Estuaries: Where the River Meets the Sea I Learn Science at Scitable. Nat. Educ. Knowl. $2013,4,12$.

25. Bate, G.C.; Whitfield, A.K.; Adams, J.B.; Huizinga, P.; Wooldridge, T.H. The Importance of the River-Estuary Interface (REI) Zone in Estuaries. Water SA 2002, 28, 271-280. [CrossRef]

26. Noe, G.B.; Bourg, N.A.; Krauss, K.W.; Duberstein, J.A.; Hupp, C.R. Watershed and Estuarine Controls Both Influence Plant Community and Tree Growth Changes in Tidal Freshwater Forested Wetlands along Two U.S. Mid-Atlantic Rivers. Forests 2021, 12, 1182. [CrossRef]

27. Alkarkhi, A.F.M.; Ismail, N.; Ahmed, A.; Easa, A. mat Analysis of Heavy Metal Concentrations in Sediments of Selected Estuaries of Malaysia-a Statistical Assessment. Environ. Monit. Assess. 2009, 153, 179-185. [CrossRef] [PubMed]

28. Weiss, A.L.; Caravanos, J.; Blaise, M.J.; Jaeger, R.J. Distribution of Lead in Urban Roadway Grit and Its Association with Elevated Steel Structures. Chemosphere 2006, 65, 1762-1771. [CrossRef] [PubMed]

29. US EPA. Recommendations for Sieving Soil and Dust Samples at Lead Sites for Assessment of Incidental Ingestion; OLEM Directive 9200.1-128; United States Environmental Protection Agency: Washington, DC, USA, 2016; p. 20460.

30. Badri, M.A.; Aston, S.R. Observations on Heavy Metal Geochemical Associations in Polluted and Non-Polluted Estuarine Sediments. Environ. Pollut. Ser. B Chem. Phys. 1983, 6, 181-193. [CrossRef]

31. Yap, C.K.; Arifin, N.; Tan, S.G. Relationships of Copper Concentrations between the Different Soft Tissues of Telescopium Telescopium and the Surface Sediments Collected from Tropical Intertidal Areas. Int. J. Chem. 2013, 5, 8-19. [CrossRef]

32. Fatoki, O.S.; Awofolu, R. Levels of Cd, Hg and Zn in Some Surface Waters from the Eastern Cape Province, South Africa. Water SA 2003, 29, 375-380. [CrossRef]

33. Ikem, A.; Egiebor, N.O.; Nyavor, K. Trace Elements in Water, Fish and Sediment from Tuskegee Lake, Southeastern Usa. Water Air Soil Pollut. 2003, 149, 51-75. [CrossRef]

34. Yao, Z.G.; Bao, Z.Y.; Gao, P.; Zhang, J.L.; Guo, Y.P.; Hu, Z.J.; Li, B.L. Speciation of Trace Elements in Sediments from Dongting Lake, Central China. In Water Pollution VIII: Modelling, Monitoring and Management; WIT Press: Bologna, Italy, 2006; Volume 1, pp. 119-128.

35. Zhao, S.; Feng, C.; Yang, Y.; Niu, J.; Shen, Z. Risk Assessment of Sedimentary Metals in the Yangtze Estuary: New Evidence of the Relationships between Two Typical Index Methods. J. Hazard. Mater. 2012, 241-242, 164-172. [CrossRef]

36. Perin, G.; Craboledda, L.; Lucchese, M.; Cirillo, R.; Dotta, L.; Zanetta, M.L.; Oro, A.A. Heavy Metal Speciation in the Sediments of Northern Adriatic Sea, A New Approach for Environmental Toxicity Determination. In Heavy Metals in the Environment; Lakkas, T.D., Ed.; CEP Consultants: Edinburgh, UK, 1985; Volume 2.

37. Wedepohl, K.H. The Composition of the Continental Crust. Geochim. Cosmochim. Acta 1995, 59, 1217-1232. [CrossRef]

38. Yap, C.K.; Noorhaidah, A. Gill and Digestive Caecum of Telescopium Telescopium as Biomonitors of Pb Bioavailability and Contamination by $\mathrm{Pb}$ in the Tropical Intertidal Area. Sains Malays. 2011, 40, 1075-1085.

39. Yap, C.K.; Noorhaidah, A.; Tan, S.G. Zn Concentrations in the Different Soft Tissues of Telescopium Telescopium and Their Relationships with Zn Speciation by Sequential Extraction in Surface Sediments: A Statistical Multiple Linear Stepwise Regression Analysis. In Gastropods: Diversity, Habitat, and Genetics; Branchi, A.M., Fields, J.N., Eds.; Nova Science Publishers Inc.: New York, NY, USA, 2011; pp. 127-148. ISBN 978-1-61324-695-5. 
40. Hakanson, L. An Ecological Risk Index for Aquatic Pollution Control.a Sedimentological Approach. Water Res. 1980, 14, 975-1001. [CrossRef]

41. Cheng, W.H.; Yap, C.K. Potential Human Health Risks from Toxic Metals via Mangrove Snail Consumption and Their Ecological Risk Assessments in the Habitat Sediment from Peninsular Malaysia. Chemosphere 2015, 135, 156-165. [CrossRef]

42. Xiao, Y.; Guo, M.; Li, X.; Luo, X.; Pan, R.; Ouyang, T. Spatial Distribution, Pollution, and Health Risk Assessment of Heavy Metal in Agricultural Surface Soil for the Guangzhou-Foshan Urban Zone, South China. PLoS ONE 2020, 15, e0239563. [CrossRef]

43. Soltani, N.; Keshavarzi, B.; Moore, F.; Tavakol, T.; Lahijanzadeh, A.R.; Jaafarzadeh, N.; Kermani, M. Ecological and Human Health Hazards of Heavy Metals and Polycyclic Aromatic Hydrocarbons (PAHs) in Road Dust of Isfahan Metropolis, Iran. Sci. Total Environ. 2015, 505, 712-723. [CrossRef]

44. Zhao, W.; Gu, C.; Ying, H.; Feng, X.; Zhu, M.; Wang, M.; Tan, W.; Wang, X. Fraction Distribution of Heavy Metals and Its Relationship with Iron in Polluted Farmland Soils around Distinct Mining Areas. Appl. Geochem. 2021, 130, 104969. [CrossRef]

45. US EPA. Baseline Human Health Risk Assessment Vasquez Boulevard and I-70 Superfund Site Denver, CO; US Environmental Protection Agency: Denver, FL, USA, 2001.

46. US EPA. Exposure Factors Handbook; National Center for Environmental Assessment, US EPA Office of Research and Development: Washington, DC, USA, 1997; ISBN EPA/600/P-95/002F.

47. US EPA. Human Health Evaluation Manual. In Risk Assessment Guidance for Superfund; Office of Emergency and Remedial Response, U.S. Environmental Protection Agency: Washington, DC, USA, 1989; Volume 1, ISBN EPA/540/1-89/002.

48. US EPA. Superfund Public Health Evaluation Manual; U.S. Environmental Protection Agency: Washington, DC, USA, 1986 ; pp. 1-86.

49. Chabukdhara, M.; Nema, A.K. Heavy Metals Assessment in Urban Soil around Industrial Clusters in Ghaziabad, India: Probabilistic Health Risk Approach. Ecotoxicol. Environ. Saf. 2013, 87, 57-64. [CrossRef]

50. Qing, X.; Yutong, Z.; Shenggao, L. Assessment of Heavy Metal Pollution and Human Health Risk in Urban Soils of Steel Industrial City (Anshan), Liaoning, Northeast China. Ecotoxicol. Environ. Saf. 2015, 120, 377-385. [CrossRef]

51. Hu, X.; Zhang, Y.; Luo, J.; Wang, T.; Lian, H.; Ding, Z. Bioaccessibility and Health Risk of Arsenic, Mercury and Other Metals in Urban Street Dusts from a Mega-City, Nanjing, China. Environ. Pollut. 2011, 159, 1215-1221. [CrossRef]

52. Ferreira-Baptista, L.; De Miguel, E. Geochemistry and Risk Assessment of Street Dust in Luanda, Angola: A Tropical Urban Environment. Atmos. Environ. 2005, 39, 4501-4512. [CrossRef]

53. Kelepertzis, E. Investigating the Sources and Potential Health Risks of Environmental Contaminants in the Soils and Drinking Waters from the Rural Clusters in Thiva Area (Greece). Ecotoxicol. Environ. Saf. 2014, 100, 258-265. [CrossRef] [PubMed]

54. Li, Z.; Ma, Z.; van der Kuijp, T.J.; Yuan, Z.; Huang, L. A Review of Soil Heavy Metal Pollution from Mines in China: Pollution and Health Risk Assessment. Sci. Total Environ. 2014, 468-469, 843-853. [CrossRef] [PubMed]

55. Hair, J.F.; Black, W.C.; Babin, B.J. Multivariate Data Analysis: A Global Perspective; Pearson Education: Upper Saddle River, NJ, USA, 2010; ISBN 978-0-13-515309-3.

56. Byrne, B.M. Structural Equation Modeling with AMOS: Basic Concepts, Applications, and Programming, 2nd ed.; Routledge: New York, NY, USA, 2010; ISBN 978-0-203-80553-4.

57. Ismail, A.; Safahieh, A. Copper and Zinc in Intertidal Surface Sediment and Telescopium Telescopium from Lukut River, Malaysia. Coast Mar. Sci. 2005, 29, 111-115.

58. Saed, K.; Ismail, A.; Omar, H.; Kusnan, M. Accumulation of Heavy Metals (Zn, Cu, Pb, Cd) in Flat-Tree Oysters Isognomon Alatus Exposed to Pig Farm Effluent. Toxicol. Environ. Chem. 2002, 82, 45-58. [CrossRef]

59. Yap, C.K.; Chew, W.; Al-Mutairi, K.A.; Al-Shami, S.A.; Nulit, R.; Ibrahim, M.H.; Wong, K.W.; Bakhtiari, A.R.; Sharifinia, M.; Cheng, W.H.; et al. Invasive Weed Asystasia Gangetica as a Potential Biomonitor and a Phytoremediator of Potentially Toxic Metals: A Case Study in Peninsular Malaysia. Int. J. Environ. Res. Public. Health 2021, 18, 4682. [CrossRef] [PubMed]

60. Saed, K.; Ismail, A.; Omar, H.; Kusnan, M. Heavy Metal Depuration in Flat Tree Oysters Isognomon Alatus under Field and Laboratory Conditions. Toxicol. Environ. Chem. 2004, 86, 171-179. [CrossRef]

61. Hossain, M.; Othman, S.; Bujang, J.S.; Lim, M.T. Distribution of Copper in the Sepang Mangrove Reserve Forest Environment, Malaysia. J. Trop. For. Sci. 2001, 13, 130-139.

62. Taylor, S.R.; McLennan, S.M. The Geochemical Evolution of the Continental Crust. Rev. Geophys. 1995, 33, 241-265. [CrossRef]

63. Rudnick, R.L.; Gao, S. 3.01-Composition of the Continental Crust. In Treatise on Geochemistry; Holland, H.D., Turekian, K.K., Eds.; Pergamon: Oxford, UK, 2003; pp. 1-64. ISBN 978-0-08-043751-4.

64. Saleem, M.; Iqbal, J.; Shah, M.H. Geochemical Speciation, Anthropogenic Contamination, Risk Assessment and Source Identification of Selected Metals in Freshwater Sediments-A Case Study from Mangla Lake, Pakistan. Environ. Nanotechnol. Monit. Manag. 2015, 4, 27-36. [CrossRef]

65. Mondal, P.; Schintu, M.; Marras, B.; Bettoschi, A.; Marrucci, A.; Sarkar, S.; Chowdhury, R.; Jonathan, M.P.; Biswas, J. Geochemical Fractionation and Risk Assessment of Trace Elements in Sediments from Tide-Dominated Hooghly (Ganges) River Estuary, India. Chem. Geol. 2020, 532, 119373. [CrossRef]

66. Chua, K.B. Nipah Virus Outbreak in Malaysia. J. Clin. Virol. Off. Publ. Pan Am. Soc. Clin. Virol. 2003, 26, 265-275. [CrossRef]

67. Zhu, J.; Li, R.; Zhang, Z.; Mao, H.; Fan, Z. Heavy Metal Contents in Pig Manure and Feeds under Intensive Farming and Potential Hazard on Farmlands in Shaanxi Province, China. Trans. Chin. Soc. Agric. Mach. 2013, 44, 98-104. [CrossRef]

68. Zhang, D.; Wang, X.; Zhou, Z. Impacts of Small-Scale Industrialized Swine Farming on Local Soil, Water and Crop Qualities in a Hilly Red Soil Region of Subtropical China. Int. J. Environ. Res. Public Health 2017, 14, 1524. [CrossRef] [PubMed] 
69. Moral, R.; Perez-Murcia, M.D.; Perez-Espinosa, A.; Moreno-Caselles, J.; Paredes, C.; Rufete, B. Salinity, Organic Content, Micronutrients and Heavy Metals in Pig Slurries from South-Eastern Spain. Waste Manag. 2008, 28, 367-371. [CrossRef] [PubMed]

70. Marszałek, M.; Kowalski, Z.; Makara, A. The Possibility of Contamination of Water-Soil Environment as a Result of the Use of Pig Slurry. Ecol. Chem. Eng. S 2019, 26, 313-330. [CrossRef]

71. Jensen, J.; Kyvsgaard, N.C.; Battisti, A.; Baptiste, K.E. Environmental and Public Health Related Risk of Veterinary Zinc in Pig Production-Using Denmark as an Example. Environ. Int. 2018, 114, 181-190. [CrossRef]

72. Benedet, L.; Comin, J.; Pescador, R.; Oliveira, P.; Filho, P.; De Conti, L.; Couto, R.; Lovato, P.; Cesco, S.; Mimmo, T.; et al. Physiological Changes in Maize Grown in Soil with Copper and Zinc Accumulation Resulting from the Addition of Pig Slurry and Deep Litter over 10 Years. Water. Air. Soil Pollut. 2016, 227, 401. [CrossRef]

73. Bo, L.; Li, Y.; Luo, J.; Zhang, Y.; Jing, Y.; Liu, Z. Characteristics of Heavy Metals Pollution in Pig Manures and Environmental Risks Evaluation in Intensive Pig Farming Areas in China. Nongye Jixie XuebaoTransactions Chin. Soc. Agric. Mach. 2018, 49, 258-267. [CrossRef]

74. Bonneau, M.; Béline, F.; Dourmad, J.-Y.; Hassouna, M.; Jondreville, C.; Loyon, L.; Morvan, T.; Paillat, J.; Ramonet, Y.; Robin, P. Elements of Waste from Pigs: Knowledge and Control. Prod. Anim. 2008, 21, 325-343.

75. Ya, N.A.; Singh, H.R.; Ramli, N.H.; Makhtar, N.I.; Mohd Rashid, H.N.; Dzakaria, N.; Samat, A. Fish Diversity in Sepang Besar Estuary-A Preliminary Analysis. Int. J. Adv. Agric. Environ. Eng. 2015, 1, 229-233. [CrossRef]

76. Hu, M.; Wang, C.; Liu, Y.; Zhang, X.; Jian, S. Fish Species Composition, Distribution and Community Structure in the Lower Reaches of Ganjiang River, Jiangxi, China. Sci. Rep. 2019, 9, 10100. [CrossRef] [PubMed]

77. DoE Malaysia. Malaysia Environmental Quality Report 2010; Publication Section, Strategic Communications Division, Department of Environment, Ministry of Natural Resources and Environment Malaysia: Putrajaya, Malaysia, 2010.

78. Wei, J.; Duan, M.; Li, Y.; Nwankwegu, A.S.; Ji, Y.; Zhang, J. Concentration and Pollution Assessment of Heavy Metals within Surface Sediments of the Raohe Basin, China. Sci. Rep. 2019, 9, 13100. [CrossRef] [PubMed]

79. Hossain, M.S.; Ahmed, M.K.; Liyana, E.; Hossain, M.S.; Jolly, Y.N.; Kabir, M.J.; Akter, S.; Rahman, M.S. A Case Study on Metal Contamination in Water and Sediment near a Coal Thermal Power Plant on the Eastern Coast of Bangladesh. Environments 2021, 8, 108. [CrossRef]

80. Dendievel, A.-M.; Mourier, B.; Dabrin, A.; Delile, H.; Coynel, A.; Gosset, A.; Liber, Y.; Berger, J.-F.; Bedell, J.-P. Metal Pollution Trajectories and Mixture Risk Assessed by Combining Dated Cores and Subsurface Sediments along a Major European River (Rhône River, France). Environ. Int. 2020, 144, 106032. [CrossRef] [PubMed]

81. Moore, J.N.; Langner, H.W. Can a River Heal Itself? Natural Attenuation of Metal Contamination in River Sediment. Environ. Sci. Technol. 2012, 46, 2616-2623. [CrossRef]

82. Edwards, L.; Crabb, H. Water Quality and Management in the Australian Pig Industry. Anim. Prod. Sci. 2021, 61, 637. [CrossRef]

83. Hu, Z.; Chu, Y.; Ma, Y. Design of a Combined Constructed Wetland System and Its Application on Swine Wastewater Treatment. J. Environ. Eng. 2020, 146, 04019093. [CrossRef]

84. Li, Z.; Liu, D.; XiaoCheng, W.; Yu, S. Removing Cu and Zn from pig manure via the leaching method with EDTA, saponin, and their mixture. J. Agro-Environ. Sci. 2019, 38, 220-228.

85. Kwan, C.; Chong, V.; Sasekumar, A.; Leong, L.F. Resource Valuation of Kuala Selangor Mangrove Forest in Book Titled Ecology of Klang Strait; University Malaya: Kuala Lumpur, Malaysia, 2005; ISBN 983-100-304-7.

86. Getzner, M.; Islam, M.S. Ecosystem Services of Mangrove Forests: Results of a Meta-Analysis of Economic Values. Int. J. Environ. Res. Public Health 2020, 17, 5830. [CrossRef] 